\title{
Impaired Fast-Spiking, Suppressed Cortical Inhibition, and Increased Susceptibility to Seizures in Mice Lacking Kv3.2 K ${ }^{+}$ Channel Proteins
}

\author{
David Lau, ${ }^{1}$ Eleazar Vega-Saenz de Miera, ${ }^{1}$ Diego Contreras, ${ }^{2}$ Ander Ozaita, ${ }^{1}$ Michael Harvey, ${ }^{1}$ Alan Chow, ${ }^{1}$ \\ Jeffrey L. Noebels, ${ }^{3}$ Richard Paylor, ${ }^{4}$ James I. Morgan, ${ }^{5}$ Christopher S. Leonard ${ }^{6}$ and Bernardo Rudy ${ }^{1}$ \\ ${ }^{1}$ Departments of Physiology and Neuroscience, and Biochemistry, New York University School of Medicine, New York, \\ New York 10016, 2Department of Neuroscience, University of Pennsylvania School of Medicine, Philadelphia, Pennsylvania \\ 19106, Departments of 3Neurology and ${ }^{4}$ Molecular and Human Genetics, Baylor College of Medicine, Houston, Texas, \\ 77030, 5Department of Developmental Neurobiology, St. Jude Children's Research Hospital, Memphis, Tennessee 38105, \\ and ${ }^{6}$ Department of Physiology, New York Medical College, Valhalla, New York 10595
}

\begin{abstract}
Voltage-gated $\mathrm{K}^{+}$channels of the $\mathrm{Kv} 3$ subfamily have unusual electrophysiological properties, including activation at very depolarized voltages (positive to $-10 \mathrm{mV}$ ) and very fast deactivation rates, suggesting special roles in neuronal excitability. In the brain, Kv3 channels are prominently expressed in select neuronal populations, which include fast-spiking (FS) GABAergic interneurons of the neocortex, hippocampus, and caudate, as well as other high-frequency firing neurons. Although evidence points to a key role in high-frequency firing, a definitive understanding of the function of these channels has been hampered by a lack of selective pharmacological tools. We therefore generated mouse lines in which one of the Kv3 genes, Kv3.2, was disrupted by gene-targeting methods. Whole-cell electrophysiological recording showed that the ability to fire spikes at high frequencies was impaired in immunocytochemically identified FS interneurons of deep cortical layers (5-6) in which Kv3.2 proteins are normally
\end{abstract}

prominent. No such impairment was found for FS neurons of superficial layers (2-4) in which Kv3.2 proteins are normally only weakly expressed. These data directly support the hypothesis that Kv3 channels are necessary for high-frequency firing. Moreover, we found that Kv3.2 -/- mice showed specific alterations in their cortical EEG patterns and an increased susceptibility to epileptic seizures consistent with an impairment of cortical inhibitory mechanisms. This implies that, rather than producing hyperexcitability of the inhibitory interneurons, Kv3.2 channel elimination suppresses their activity. These data suggest that normal cortical operations depend on the ability of inhibitory interneurons to generate high-frequency firing.

Key words: $K^{+}$channels; neocortex; fast spiking; knock-out inhibitory interneurons; high-frequency firing; seizure susceptibility; GABA; epilepsy
Approximately $10-20 \%$ of the neurons in the cerebral cortex are inhibitory GABAergic interneurons. These cells play a critical role in a number of important functions, including the gating and processing of sensory information, the establishment and plasticity of sensory receptive fields, the synchronization of cortical circuits, the generation of rhythms, and the limiting of seizure activity (Fairen et al., 1984; Gilbert, 1993; Jones, 1993; Amitai and Connors, 1995; Keller, 1995; Singer and Gray, 1995; Freund and Buzsaki, 1996; Jefferys et al., 1996; Steriade, 1997).

Cortical GABAergic interneurons represent a heterogenous population of cells with subtypes differing in morphological appearance, expression of specific markers such as calcium-binding proteins or neuropeptides, firing patterns, synaptic properties, and axonal connectivity (Jones, 1975; Somogyi et al., 1984; Hendry et al., 1989; Freund and Buzsaki, 1996; Cauli et al., 1997; Gonchar and Burkhalter, 1997; Kawaguchi and Kubota, 1997; Gupta et al., 2000).

The largest group of neocortical inhibitory interneurons $(\sim 50 \%)$ consists of cells that contain the calcium-binding protein parvalbumin (PV). These neurons are characterized by a "fast-spiking" firing pattern, i.e., the ability to fire long trains of very brief action potentials at high frequency with little firing frequency adaptation

\footnotetext{
Received Aug. 18, 2000; revised Sept. 7, 2000; accepted Sept. 18, 2000.

This work was supported by grants from the National Institutes of Health, American Lebanese Syrian Associated Charities, and the National Science Foundation. D.L. was supported by the Medical Scientists Training Program grant at New York University School of Medicine.

Correspondence should be addressed to Dr. Bernardo Rudy, Department of Physiology and Neuroscience, New York University School of Medicine, 550 First Avenue, New York, NY 10016. E-mail: Rudyb01@med.nyu.edu.

Copyright (C) 2000 Society for Neuroscience 0270-6474/00/209071-15\$15.00/0
}

(McCormick et al., 1985; Celio, 1986; Cauli et al., 1997; Kawaguchi and Kubota, 1997). These neurons are interconnected by electrical synapses and form a network of fast-spiking cells, suggesting a role in the generation of synchronized cortical activity (Galarreta and Hestrin, 1999; Gibson et al., 1999).

Several lines of evidence have led to the hypothesis that specific voltage-gated, delayed rectifier-type $\mathrm{K}^{+}$channels composed of $\mathrm{K}^{+}$ channel pore-forming subunits of the Kv3 subfamily (Kv3.1-Kv3.3) are critical for the ability of neurons to fire at high frequencies in a sustained or repetitive fashion. First, the properties of these channels, which include activation at voltages positive to $-10 \mathrm{mV}$ and very fast deactivation rates on membrane repolarization, naturally lend themselves to a specific role in spike repolarization. Second, there is a strong correlation between the specific expression of $\mathrm{Kv} 3$ RNA transcripts and Kv3 proteins in neuronal populations that fire at high frequencies. Third, pharmacological experiments show that blockade of native Kv3-like currents with low concentrations of tetraethylammonium (TEA) or 4-aminopyridine (4-AP) impairs the ability of these neurons to fire sustained and/or repetitiveaction potentials at high frequency. Fourth, computer modeling indicates that selective blockade of Kv3 currents impairs highfrequency firing (Perney et al., 1992; Lenz et al., 1994; Weiser et al., 1994, 1995; Du et al., 1996; Massengill et al., 1997; Sekirnjak et al., 1997; Martina et al., 1998; Wang et al., 1998; Chow et al., 1999; Erisir et al., 1999; Atzori et al., 2000) (for review, see Coetzee et al., 1999; Rudy et al., 1999).

To further test the hypothesis, and given the absence of selective channel blockers, we used gene-targeting methods to produce mice lines that do not express $\mathrm{Kv} 3.2 \mathrm{~K}^{+}$channel subunits (McCormack et al., 1990; Rudy et al., 1992), which are prominently expressed in $\mathrm{PV}$-containing interneurons in deep cortical layers (Chow et al., 
Figure 1. Generation of the Kv3.2 -/mouse. $A$, Targeting the Kv3.2 gene via homologous recombination. Top, Restriction map of the mouse genome in the area around exon I (the first coding exon) of the Kv3.2 gene. Exon I is indicated as the solid box and introns as lines. Arrows under genetic elements indicate transcriptional orientation. Middle, Kv3.2 gene-targeting vector. The neomycin resistance gene replaced the portion of exon I downstream of the EcoRI site and $\sim 4 \mathrm{~kb}$ of intron I. PGK-Neo, Neomycin resistance gene driven by the phosphoglycerate kinase promoter; $P G K$ $T K$, thymidine kinase gene driven by the phosphoglycerate kinase promoter; pBluescript, bacterial vector backbone. Crosses indicate crossover regions in homologous recombination. Bottom, Null Kv3.2 allele generated after proper targeting. The $5^{\prime}$ probe is the $X b a \mathrm{I}-S a c \mathrm{I}$ fragment used as a template to synthesize the probe for genotyping. As indicated, the 5' probe should identify a $3.0 \mathrm{~kb}$ fragment in the wild-type allele and a $5.0 \mathrm{~kb}$ band in the null allele when genomic DNA is digested with $X b a \mathrm{I}$. Restriction enzymes are as follows: $E$, EcoRI; H, HindIII; S, SacI; $X, X b a \mathrm{I}$. $B-D$, Molecular characterization of Kv3.2 knock-out mice. $B$, Genotyping by Southern blot analysis. Genomic DNA was isolated from tail biopsies of juvenile mice and digested with $X b a$ I. Kv3.2 knock-out (-/-) mice possess two copies of the engineered null allele and consequently only show the $5.0 \mathrm{~kb}$ fragment after hybridization with the ${ }^{32} \mathrm{P}$-labeled $5^{\prime}$ probe. Heterozygotes $(+/-)$ show both wild-type and mutant alleles, and the wild-type $(+/+)$ littermates only possess wild-type alleles. $C$, Northern analysis of Kv3.1 and Kv3.2 mRNA expression in Kv3.2 null mice. Ten micrograms of total brain RNA was loaded into each lane

from a wild-type, a heterozygote, and a Kv3.2 knock-out mouse. The Northern blots were probed with Kv3.2 (right) or Kv3.1 (left) ${ }^{32} \mathrm{P}-\mathrm{labeled}$ cDNA probes. Notice that the Kv3.2 knock-out does not express mature Kv3.2 RNA species and the heterozygote has lower expression levels than the wild type. In all three Kv3.2 genotypes, Kv3.1 mRNA levels are constant. The blots were then hybridized with $\beta$-actin cDNA probe to quantitate the amount of RNA per lane. The sizes of the RNA standard marker for both blots are located on the left. $D$, Immunoblots of Kv3.1b and Kv3.2 proteins in the Kv3.2 mutant. Solubilized brain membrane proteins from mice of all three genotypes were electrophoresed in SDS-PAGE gels and incubated with primary antibody against Kv3.1b (left) or Kv3.2 (right). Kv3.2 proteins were not detectable in the Kv3.2 null mutant, and lower levels of protein were present in the heterozygote animal. The concentration of Kv3.1b protein was consistent between all three genotypes. Sizes of the protein size markers are indicated at the left of each blot.

1999), and compared the properties of fast-spiking neurons in the neocortex from these mice with those from normal wild-type littermates. Results from these experiments provide direct evidence that Kv3 channels are critical for both sustained and repetitive high-frequency firing. Moreover, the Kv3.2 - / - mice show both an enhanced susceptibility to seizures and disturbed cortical rhythmic activity. The availability of mice in which fast-spiking is compromised in specific neuronal populations provides a model to investigate the consequences of this impairment on the behavior of cortical circuits, which in turn can help in the understanding of the function of fast-spiking, the roles of the interneurons in cortical function, and the mechanisms by which they achieve these functions.

\section{MATERIALS AND METHODS}

\section{Generation of mice lacking Kv3.2 proteins}

Isolation of a mouse 129 genomic clone containing exon I of Kv3.2. A mouse 129 genomic library $\left(\sim 1 \times 10^{6} \mathrm{pfu}\right)$ in $\lambda$ DashII (kind gift from Drs. J. Rossant and A. G. Reaume, Mount Sinai Hospital, Toronto, Canada) was screened at high stringency with a $380 \mathrm{bp}$ fragment containing the first 301 bp of the coding region of $\mathrm{Kv} 3.2$ and $79 \mathrm{bp}$ of the $5^{\prime}$ untranslated region, derived from a rat Kv3.2 cDNA (McCormack et al., 1990).

Bacteriophage DNA from positive clones was isolated with the Midi $\lambda$ Phage DNA Prep (Qiagen, Hilden, Germany) from fresh liquid lysates. Genomic clone inserts were excised from the bacteriophage arms by restriction digest with NotI and subcloned into the NotI site of the bacterial vector pBluescript (Stratagene, La Jolla, CA). One of the isolated clones, E2, shown by hybridization to contain sequence from the first coding exon (exon I) of Kv3.2, was used for these studies. The restriction recognition sites of the following enzymes were mapped on the E2 clone: BamHI, ClaI, $E c o$ RI, HindIII, SacI, and XbaI. Each of the EcoRI fragments was subcloned individually into pBluescript (Stratagene) to facilitate mapping and the generation of the targeting construct. The $3^{\prime}$ half of the clone E2, consisting of two contiguous EcoRI fragments of 3.6 and $8.5 \mathrm{~kb}$, was used for the construction of the targeting construct and is illustrated in Figure $1 \mathrm{~A}$.

Generation of the targeting construct. Regions within the 3.6 and $8.5 \mathrm{~kb}$ EcoRI fragments of the clone E2 were selected to be the short and long arms of homology (Fig. $1 A$ ). The $1.9 \mathrm{~kb}$ short arm of homology was isolated from the $3.6 \mathrm{~kb} E c o$ RI fragment by digestion with $S a c \mathrm{I}$ and EcoRI. The $5.0 \mathrm{~kb}$ long arm of homology was isolated from the $8.5 \mathrm{~kb}$ EcoRI fragment by restriction digestion with $X b a \mathrm{I}$ and NotI (in the polylinker of pBluescript). The neomycin resistance gene flanked by EcoRI and XbaI sticky ends was ligated between the two arms. The thymidine kinase gene was placed $5^{\prime}$ of the short arm of homology, and the entire construct was cloned into pBluescript. The final construct was mapped by restriction digest and subsequent Southern hybridization, as well as by sequencing of key junctions to confirm its integrity. $\left(\right.$ ES) cells $\left(28 \times 10^{6}\right)$ were harvested (Robertson, 1987) and resuspended in $1 \mathrm{ml}$ of culture medium in a sterile electroporation cuvette (Bio-Rad, Hercules, CA). We mixed $40 \mu \mathrm{g}$ of the Not I linearized targeting construct (in sterile PBS) with the suspended cells and electroporated it with a Gene-Pulser electroporator (Bio-Rad) at $0.23 \mathrm{kV}, 500 \mu \mathrm{F}$. The pulsed ES cells were cultured onto $60 \mathrm{~mm}$ feeder plates at $37^{\circ} \mathrm{C}$ in an atmosphere of $5 \% \mathrm{CO}_{2}$. The basic culture medium consisted of DMEM plus $15 \%$ serum. Leukemia inhibitory factor $\left(10^{6} \mathrm{U} / \mathrm{ml}\right)$, used to retard ES cell differentiation, was added to all culture media except replica plates (see below). After a day in culture, G418 $(350 \mu \mathrm{g} / \mathrm{ml}$ Geneticin; Life Technologies, Gaithersburg, MD) and 1-(2-deoxy-2-fluoro-1- $\beta$-D-arabino-furanosyl)-5iodouracil $(2 \mu \mathrm{g} / \mathrm{ml}$; a gift from Eli Lilly, Indianapolis, IN) were added to the culture medium. The medium was changed $2 \mathrm{~d}$ after drug introduction and then daily afterward. Five days after drug introduction, surviving undifferentiated ES cell colonies were transferred individually to multiwell cell culture plates (Falcon).

A total of $380 \mathrm{ES}$ cell colonies were harvested. The medium was changed $2 \mathrm{~d}$ after harvesting and then daily. Four days later, the ES cell cultures were trypsinized and passaged into two sterile 48-well multiwell cell
Homologous recombination in embryonic stem cells. W9.5 embryonic stem 
culture plates (one colony per well), a master plate that was frozen and stored at $-70^{\circ} \mathrm{C}$, and a replica plate that was further expanded. The replica plates were fed every $2 \mathrm{~d}$. After 1 week in culture, the cell culture medium was discarded, and the replica plates were washed with PBS. To each well, $250 \mu \mathrm{l}$ of lysis buffer $(1.0 \mathrm{M} \mathrm{NaCl}, 10 \mathrm{~mm}$ EDTA, $50 \mathrm{~mm}$ Tris, $\mathrm{pH} 8,0.5 \%$ SDS, and $0.2 \mu \mathrm{g} / \mu \mathrm{l}$ proteinase $\mathrm{K}$ ) was added, and the plate was incubated overnight at $55^{\circ} \mathrm{C}$. We added $250 \mu \mathrm{l}$ of isopropanol to each well and the genomic DNA pellets were transferred individually to microcentrifuge tubes. The DNA was washed with $70 \%$ ethanol and resuspended in $50 \mu \mathrm{l}$ of Tris-EDTA (TE). The DNA was used to genotype the colonies by Southern blot analysis (as described below) to identify ES cells that had undergone homologous recombination.

Chimera generation. From the master plate, identified, targeted ES cell colonies were expanded in culture. C57BL6 blastocysts that were $2.5 \mathrm{~d}$ old were harvested from the uterine tubes of timed pregnant females, and 8-10 targeted ES cells were introduced to the blastocoel with a beveled glass micropipette. The injected blastocysts were implanted into pseudopregnant mothers (Joyner, 2000). Chimeric character was estimated by coat color, and males with $>95 \%$ chimerism were selected and bred with C57BL6 females. Offspring heterozygotes were identified by Southern blot genotyping using genomic DNA obtained from tail biopsies (see below) and were bred against C57BL6 mice for backcrossing or bred against other heterozygotes to generate knock-out mice. All knock-out mice used in our experiments had been backcrossed at least seven generations onto the C57BL6 genetic background.

\section{Genotyping by genomic Southern blot analysis}

Genomic DNA from cultured ES cells or tail biopsies was digested overnight with $X b a I$ (Promega, Madison, WI). The digested samples were electrophoresed on $0.7 \%$ agarose-Tris-borate-EDTA gels at 7.5-9.0 V/cm until DNA fragment sizes from 2 to $6 \mathrm{~kb}$ were clearly separated. The gels were stained with ethidium bromide and photographed on a UV light table with a fluorescent ruler for orientation. The agarose gels were incubated in 5 gel volumes of denaturing solution $(1.0 \mathrm{M} \mathrm{NaOH}$ and $1.5 \mathrm{M} \mathrm{NaCl})$ with gentle agitation for $30 \mathrm{~min}$ and a change to a fresh solution after $15 \mathrm{~min}$. After denaturing, the gels were incubated in 5 gel volumes of neutralizing solution $(1.0 \mathrm{M}$ Tris- $\mathrm{HCl}, \mathrm{pH} 7.5$, and $1.5 \mathrm{M} \mathrm{NaCl})$ with gentle agitation for $30 \mathrm{~min}$ and a change to a fresh solution after $15 \mathrm{~min}$. The DNA in the gels was transferred onto nylon membranes (Stratagene) overnight via capillary action. The blotted membranes were marked, and the DNA was UVcrosslinked to the nylon membrane in a Stratalinker (Stratagene). The membranes were stored dry at room temperature until hybridization.

The probe used for genotyping was a $1.0 \mathrm{~kb}$ band between the XbaI and SacI sites in the $3.6 \mathrm{~kb}$ EcoRI fragment of the E2 clone (Fig. 1A, bottom diagram). The probe corresponds to sequences in the intron preceding exon I of the Kv3.2 gene. Probes were labeled with $\left[{ }^{32} \mathrm{P}\right] \mathrm{dCTP}$ with the Redi-Prime random primer labeling kit (Amersham Pharmacia Biotech, Arlington Heights, IL). With XbaI-digested genomic DNA, the probe hybridized to a $3.0 \mathrm{~kb}$ band derived from the wild-type allele and a $5.0 \mathrm{~kb}$ band from the targeted null allele (Fig. $1 B$ ).

The Southern blots were prehybridized in QuikHyb (Stratagene) for 15 min at $68^{\circ} \mathrm{C}$. The denatured probe was added at a final concentration of $1.5 \times 10^{6}$ TCA precipitable counts per milliliter, and the blots were hybridized in a Hybaid oven (Labline) at $68^{\circ} \mathrm{C}$ for $1 \mathrm{hr}$ with gentle rotation. The hybridized Southern membranes were washed (three times) at room temperature with $2 \times$ saline-sodium phosphate-EDTA buffer (SSPE) and $0.1 \%$ SDS, followed by a $60^{\circ} \mathrm{C}$ hot wash (in $0.1 \times$ SSPE and $0.1 \%$ SDS) for $30 \mathrm{~min}$. The blots were then exposed to x-ray film between two intensifying screens at $-70^{\circ} \mathrm{C}$ for $2 \mathrm{hr}$ to 1 week, depending on the intensity of the signal.

\section{Isolation of genomic DNA from tail biopsies}

We harvested $0.5-1.0 \mathrm{~cm}$ of tail from $\sim 3$-week-old mice. Tails were digested overnight at $60^{\circ} \mathrm{C}$ in tail lysis buffer $(100 \mathrm{~mm} \mathrm{NaCl}, 50 \mathrm{~mm}$ Tris, $\mathrm{pH} 7.4,1 \mathrm{~mm}$ EDTA, $0.1 \%$ SDS, and $0.75 \mathrm{mg} / \mathrm{ml}$ proteinase K). Tail lysates were extracted with $1 \mathrm{vol}$ of chloroform, and genomic DNA was precipitated with $2 \mathrm{vol}$ of ethanol. DNA pellets were washed with $70 \%$ ethanol and briefly air-dried to remove residual ethanol. The genomic DNA was resuspended in TE and used for restriction enzyme digestion.

\section{Northern blot analysis}

Total RNA was obtained with the guanidine-isothiocynate method and quantified by optical density measurements (Chomczynski and Sacchi, 1987). Total RNA $(10 \mu \mathrm{g})$ from knock-out and wild-type mice was electrophoresed in denaturing formaldehyde gels and transferred to Duralon-UV membranes (Stratagene) as previously described (Rudy et al., 1988). The Northern blots were hybridized as described for Southern genotyping. The probe for Kv3.2 was the $380 \mathrm{bp}$ probe described previously. A full-length cDNA clone of Kv3.1b was used as a probe template for Kv3.1 mRNA detection.

\section{Western blot analysis}

Brain membrane extracts were prepared from a P3 fraction of tissue homogenate from adult knock-out and wild-type mice (Hartshorne and Catterall, 1984) and solubilized in Triton X-100 as previously described
(Chow et al., 1999). To prepare the Western blots, membrane protein (25 $\mu \mathrm{g} / \mathrm{lane}$ for detection with Kv3.1b-Ab and $50 \mu \mathrm{g} / \mathrm{lane}$ for $\mathrm{Kv} 3.2-\mathrm{Ab}$ ) were electrophoresed in a 9\% SDS polyacrylamide gel and then transferred onto nitrocellulose membranes (Bio-Rad) as previously described (Chow et al., 1999). The blots were incubated with either Kv3.1b-Ab (Weiser et al., 1995 ) at 1:1000-1:2000 dilution or Kv3.2-Ab (Chow et al., 1999) at 1:501:100 dilution. This was followed by incubation with horseradish peroxidase-linked anti-rabbit secondary antibodies (Promega). Detection of the secondary antibody was performed using chemiluminescence (Pierce, Rockford, IL). The Kv3.2-rAb was derived from immunizing rabbits to a peptide corresponding to a sequence present in the region of the Kv3.2 protein that is before the first membrane-spanning domain in the $\mathrm{N}$-terminal area and recognizes all Kv3.2 isoforms (Chow et al., 1999). The $\mathrm{Kv} 3.1-\mathrm{rAb}$ is directed against the $\mathrm{C}$ terminal of the predominant isoform of the Kv3.1 gene, Kv3.1b (Weiser et al., 1995).

\section{Immunohistochemistry of mouse brain}

Adult mice were anesthetized with intraperitoneal injections of sodium pentobarbital $(\sim 80-100 \mathrm{mg} / \mathrm{kg})$ and transcardially perfused with paraformaldehyde after the loss of pain reflexes as previously described (Chow et al., 1999). The brains were removed from the animals and processed for immunohistochemistry as described previously (Chow et al., 1999). The Vectastain Elite ABC kit was used to immunolabel via the horseradish peroxidase method. Kv3.1-rAb was used at 1:1000 dilution, Kv3.2-rAb was used at 1:300 dilution, and mouse monoclonal antibodies to parvalbumin (Sigma, St. Louis, MO) were used at 1:300.

\section{In vivo physiology}

Behavioral analysis. The following behavioral tests were all done in the laboratory of Richard Paylor (Department of Molecular and Human Genetics, Baylor College of Medicine) with a battery commonly used in this laboratory (Kimber et al., 1999; Peier et al., 2000). The tests were done blindly in a group of mice that included 13 mutant (four female, nine male) and nine wild-type (three female, six male) littermates. The mice had been backcrossed seven times to C57BL6. The tests were performed essentially as described by Paylor et al. (1998) and included the following: (1) general neurological screen for severe sensory and motor abnormalities, (2) openfield test for exploratory activity and anxiety-related responses, (3) lightdark test for anxiety-related responses, (4) rotarod test for motor coordination and skill learning, (5) acoustic startle and prepulse inhibition of the acoustic startle response for sensorimotor gating, (6) habituation of the acoustic startle response for sensorimotor adaptation, (7) contextual and auditory-cued freezing to assess conditioned fear, and (8) the hotplate test for analgesia-related responses. Data were analyzed using two- or threeway ANOVA.

Chronic EEG. Adult mice were anesthetized with Avertin (1.25\% tribromoethanol-amyl alcohol) by intraperitoneal injection $(0.02 \mathrm{ml} / \mathrm{gm})$. Silver wire electrodes $(0.005$ inches in diameter $)$ soldered to a microminiature connector were implanted into the subdural space over the left and right cortical hemispheres. After several days of recovery, EEG activity was recorded daily during random $2 \mathrm{hr}$ samples for 7-10 d using a TECA digital electroencephalograph. All recordings were performed on mice moving freely in the test cage in the laboratory of Jeffrey L. Noebels at Baylor College of Medicine.

EEG recording in anesthetized mice. Knock-out and wild-type mice were anesthetized with intraperitoneal injections of a mixture of ketamine (15 $\mathrm{mg} / \mathrm{kg}$ ) and xylazine $(3 \mathrm{mg} / \mathrm{kg})$. Depth of anesthesia was ascertained by recording EEG with monopolar electrodes placed in frontal cortex. Supplemental doses of ketamine-xylazine were given at the slightest sign of EEG desynchronization. After the loss of tail pinch reflexes, the mice were placed in a rodent stereotaxic apparatus (David Kopf Instruments, Tujunga, CA) equipped with mouse head holders. A midline sagittal incision was made along the scalp, and the skin was reflected. Petroleum jelly was applied over the eyes to prevent ulcers. Burr holes were drilled over the right somatosensory cortex and the right dorsal thalamus according to the stereotaxic coordinates (Franklin and Paxinos, 1997). Mineral oil was applied over the exposed brain to prevent desiccation. Bipolar tungsten electrodes were fashioned from two monopolar tungsten electrodes with resistance of $1 \mathrm{M} \Omega$ that were affixed with dental cement. The bipolar electrode pairs were lowered into the neocortex and thalamus with fine micromanipulators (Narishige, Tokyo, Japan) through the burr holes, and signals were amplified with a homemade DC amplifier with head stage and capacity compensation. In cortex, the electrodes were located in the pial surface and in layer $6(\sim 0.7 \mathrm{~mm}$ apart $)$; in the thalamus, the electrodes were side by side, separated by $0.4 \mathrm{~mm}$. Electrical stimulation was also delivered through the recording electrodes with an isolated pulse stimulator (AM Systems). Data were sampled at $1 \mathrm{kHz}$ with an InstruNet (GW Systems) analog-to-digital card and analyzed in Igor (WaveMetrics Inc., Lake Oswego, OR) with customized routines.

Seizure induction with pentylenetetrazole. Pentylenetetrazole (PTZ) (Research Biochemicals, Natick, MA) was dissolved in PBS and injected intraperitoneally at the indicated dose. After injection, the animal was placed in a transparent Plexiglas cage $(30 \times 20 \times 25 \mathrm{~cm})$ and observed for up to $30 \mathrm{~min}$. Latencies to focal (partial clonic), generalized (generalized clonic), and maximal (tonic-clonic) behavioral seizures were recorded. The bottom of the cage was covered with clean paper towels that were replaced 
for each animal. Each cage was cleaned with water after each experiment, before introducing a new mouse. All the animals used in this study were housed in a facility with light (12 hr light/dark cycle) and temperature control, and all the experiments were performed in the laboratory between 12:00 P.M. and 2 P.M. in mice of similar age (10-14 weeks).

We defined several stages in the behavioral response to PTZ injection. Stage 1, designated as hypoactivity, was characterized by a progressive decrease in activity until the mice stood in a crouched or prone position with their abdomens in full contact with the bottom of the cage. Stage 2 was isolated jerks or twitches. Stage 3 was partial or focal clonic seizures affecting the face, head, and/or forelimbs. These seizures were usually very brief, typically 1-2 sec. Stage 4 was generalized clonic seizures. These usually occurred suddenly, could last $30 \mathrm{sec}$ or more, and involved generalized whole-body clonus. Autonomic signs were frequently seen. The seizure was usually followed by a quiescent period. Stage 5 was tonic-clonic (maximal) seizures. Mice reaching this stage displayed wild running and jumping behavior and then had generalized seizures characterized by tonic hindlimb extension. Tonic-clonic maximal seizures were usually associated with death.

\section{In vitro physiology}

Slice preparation. Knock-out and wild-type mice of ages postnatal day 15 (P15) to P21 were used for acute brain-slice preparation (Agmon and Connors, 1991). Mice were anesthetized with an overdose injection of sodium pentobarbital and decapitated after the loss of pain reflexes. The brain was rapidly removed from the skull in a bath of ice-cold artificial CSF (ACSF) (in mM): $124 \mathrm{NaCl}, 5 \mathrm{KCl}, 1.25 \mathrm{NaH}_{2} \mathrm{PO}_{4}, 26 \mathrm{NaHCO}_{3}, 2 \mathrm{MgSO}_{4}$, $2 \mathrm{CaCl}_{2}$, and 10 dextrose, pH 7.4, bubble-saturated with $95 \% \mathrm{O}_{2}, 5 \% \mathrm{CO}_{2}$. Slices $250-\mu \mathrm{m}$-thick from the somatosensory cortex were prepared on a vibratome (World Precision Instruments, Sarasota, FL) and placed in a holding chamber with continuous bubbling ACSF at room temperature. Slices were allowed to rest in the holding chamber for at least $1 \mathrm{hr}$ before transfer to the recording chamber. The submersion-type recording chamber was perfused at a rate of $2-3 \mathrm{ml} / \mathrm{min}$ with ACSF saturated with $95 \%$ $\mathrm{O}_{2}, 5 \% \mathrm{CO}_{2}$, and all recordings were done at a temperature of $24^{\circ} \mathrm{C}$ controlled by an in-line solution heater (Warner Instruments, Hamden, CT).

Whole-cell recordings. Neocortical neurons were visualized with nearinfrared light $(>775 \mathrm{~nm})$ at $400 \times$ magnification with a nuvicon tube camera (Dage-MTI, Michigan City, IN) and differential interference optic (DIC) on a fixed-stage microscope (Olympus Optical, Tokyo, Japan) (Stuart et al., 1993; Erisir et al., 1999). Nonpyramidal cells were visually selected for current-clamp experiments. Recording microelectrodes of 6-9 $\mathrm{M} \Omega$ resistance were made from standard wall borosilicate glass (Sutter Instruments, Novato, CA) with a Flaming/Brown type micropipette pulle (Sutter Instruments). The micropipette filling solution consisted of (in $\mathrm{mM}$ ): $144 \mathrm{~K}$-gluconate, 0.2 EGTA, $3 \mathrm{MgCl}_{2}, 10$ HEPES, 4 ATP-Mg, and 0.5 GTP-Tris. For subsequent histochemistry, biocytin ( $0.2 \%$ w/v; Sigma) was added to the internal solution just before recording. In the currentclamp mode of an electronic bridge amplifier (Axon Instruments, Foster City, CA), repetitive firing, single spikes, and hyperpolarization responses were recorded in the whole-cell configuration. Protocols were delivered under the control of pClamp 7 software (Axon Instruments). Responses were sampled at $10 \mathrm{kHz}$. Neurons were held at $-70 \mathrm{mV}$ with smal injections of direct current, except during protocols for spike doublets and rebound responses when they were held at $-60 \mathrm{mV}$. Action potential shape parameters were measured from action potentials evoked by $150 \mathrm{msec}$ current steps that were just above threshold. Spike amplitude was measured as the difference between the peak and the threshold of the action potential. Spike threshold was determined by finding the potential at which the second derivative of the voltage waveform exceeded three times its SD in the period preceding spike onset. The fast afterhyperpolarization (AHP) was measured as the difference between the spike threshold and voltage minimum after the action potential peak. Maximum rates of rise and decay of the action potential were computed from the maximum and minimum of the first derivative of the voltage waveform. Spike width was measured at half the spike amplitude. Spike times were measured by determining the time at which the rising phase of the action potentia crossed a fixed-threshold potential. Instantaneous frequency (one per interspike interval) was computed from trains of action potentials evoked by $600 \mathrm{msec}$ duration pulses. Steady-state firing rate was the average of instantaneous frequency for the last five intervals of a train. Current strength was increased until spike failure occurred within the $600 \mathrm{msec}$ duration pulse. The maximum steady-state firing rate was the steady-state firing rate from the train evoked by the current strengths (at increments of $100 \mathrm{pA}$ ) before that which produced spike failure. Firing frequency adaptation was calculated by dividing the steady-state firing rate by the first instantaneous frequency of the train. All analysis was performed in customized routines in Igor and Sigma Plot. Results are reported as mean \pm SEM. TEA (Research Biochemicals) was bath-applied. Only one fastspiking neuron was recorded per brain slice.

\section{Histochemistry and immunolabeling of recorded neurons}

After electrophysiological characterization, brain slices were fixed for 1-2 $\mathrm{hr}$ at room temperature in $4 \%$ paraformaldehyde in PBS. The slices were transferred into $30 \%$ sucrose with $0.02 \%$ sodium azide and stored at $4{ }^{\circ} \mathrm{C}$.
Slices were washed three times in PBS to remove sucrose and incubated in a blocking-permeablization solution $[1 \%(\mathrm{w} / \mathrm{v})$ BSA, $0.4 \%(\mathrm{v} / \mathrm{v})$ Triton $\mathrm{X}-100$, and $10 \%(\mathrm{v} / \mathrm{v})$ normal goat serum] for $1 \mathrm{hr}$. For primary labeling, streptavidin conjugated to Cy2 (1:250 dilution; Jackson ImmunoResearch, West Grove, PA) and mouse monoclonal parvalbumin IgG (1:400) (Sigma) were incubated with the brain slices in $10 \%$ blocking solution in PBS for $7 \mathrm{~d}$ at $4^{\circ} \mathrm{C}$. The slices were washed twice in PBS and incubated with the secondary antibody, Cy3-conjugated anti-mouse $\mathrm{IgG}$, for $5 \mathrm{~d}$ at $4^{\circ} \mathrm{C}$. After three washes in PBS, the slices were mounted onto glass slides in $0.001 \mathrm{M}$ phosphate buffer and allowed to air dry. The sections were coverslipped with a polyvinyl alcohol-glycerol medium with $2 \%$ 1,4diazabicyclo[2,2,2]octane (Goslin and Banker, 1991). The sections were examined and scored on a Zeiss (Oberkochen, Germany) Axiophot epifluorescence microscope. Sections containing biocytin-labeled neurons were examined for PV immunoreactivity without knowledge of the physiological characteristics of the recorded neuron. Only sections with distinct PV immunoreactivity present at the depth of the biocytin-labeled somata, as determined using a $40 \times$ objective, were considered for scoring. This precaution was taken to reduce the possibility of falsely scoring doublelabeled cells as PV-negative because of incomplete antibody or chromophore penetration. Digital images were acquired on an Zeiss Axiovert $35 \mathrm{M}$ confocal microscope with a $40 \times$ objective lens, a scanning laser attachment, and a krypton-argon mixed-gas laser, and transferred into a graphics program (Photoshop 5.0).

\section{RESULTS}

\section{Generation of mice lacking Kv3.2 proteins}

Gene targeting by homologous recombination in ES cells (Thomas and Capecchi, 1987) was used to generate mouse lines in which the Kv3.2 gene has been disrupted. The targeting construct used to modify the mouse $K v 3.2$ gene was derived from a mouse 129 genomic clone and is shown diagrammatically in Figure $1 A$, which also illustrates the structure of the gene in the mutated area before and after the targeting. The $3^{\prime}$ end portion of the first coding exon (exon I) of Kv3.2 was deleted and replaced by a neomycin gene. The portion of exon I that was deleted encodes the subunit (or tetramerization) domain ( $\mathrm{T}$ domain) that is critical for the oligomerization of $\mathrm{Kv}$ channel subunits (Li et al., 1992; Shen and Pfaffinger, 1995; Xu et al., 1995). Therefore, if a truncated protein were to be made at the normal starting methionine of Kv3.2, it would lack the $\mathrm{T}$ domain and would not oligomerize with products of other Kv3 genes and produce dominant negative effects (McCormack et al., 1991; Babila et al., 1994; Ribera et al., 1996). ES cells with a targeted allele were selected and implanted in foster mothers. Several chimeras were obtained, from which two independent lines of Kv3.2 -/- mice were established. Both have been backcrossed ( 7 and 10 times so far) to C57BL6 mice and are being maintained in this genetic background. Kv3.2 -/- mice lack Kv3.2 mRNA and protein products (Figs. $1 C, D, 2$ ), whereas heterozygous mice have reduced mRNA and protein levels (Fig. 1C,D). In contrast, the levels of products of the closely related $K v 3.1$ gene were not affected (Fig. 1C,D). We also determined whether the distribution of Kv3.1 protein was altered in the Kv3.2 -/ - mice by immunohistochemistry (Fig. 2). Kv3.1 proteins have a wider expression pattern than Kv3.2 proteins (Weiser et al., 1995; Rudy et al., 1999) and overlap in several neuronal populations, including PV-containing neurons in the neocortex, globus pallidus, and hippocampus, in which Kv3.1 and Kv3.2 proteins may form heteromeric Kv3 channels (Chow et al., 1999; Hernandez-Pineda et al., 1999). In the Kv3.2 - / - mice, Kv3.1 proteins were detected in both these regions of overlap and the other structures in which they are normally found (Fig. 2). The overall brain histology (Fig. 2; see also Fig. 4) and the barrel structure (data not shown) of somatosensory cortex also appeared normal in these mice.

\section{Phenotypic characterization of Kv3.2 -/- mice: increased susceptibility to epileptic seizures}

Kv3.2 - /- mice in the mixed 129-C57BL6 or in the C57BL6 background have a healthy appearance and grow normally. Both male and female, homozygote $(-/-)$ and heterozygote $(+/-)$ mice are fertile. All the behavioral and functional analysis of the mice has been done in the nearly pure C57BL6 background. The mice show no evidence of severe sensory or motor abnormalities during neurological screens. Moreover, there were no significant differ- 
Kv3.2
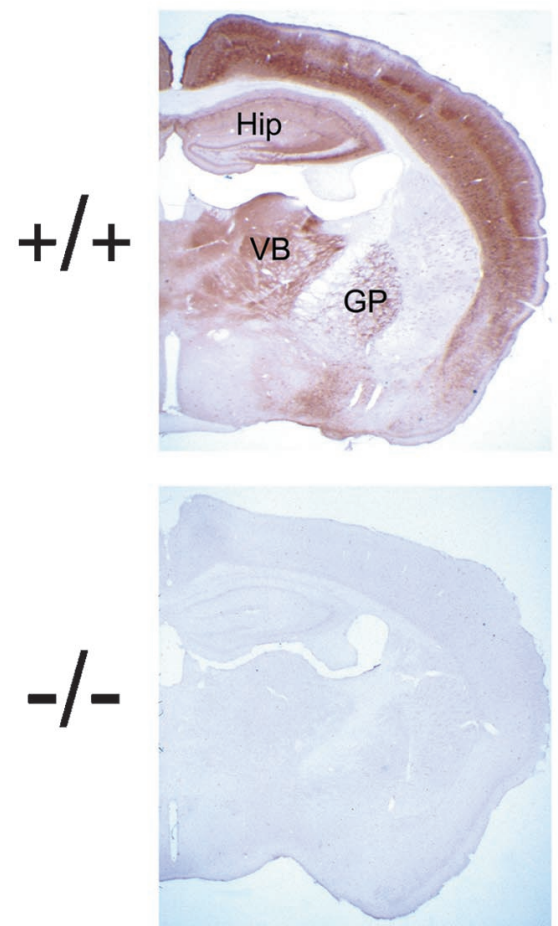

Kv3.1
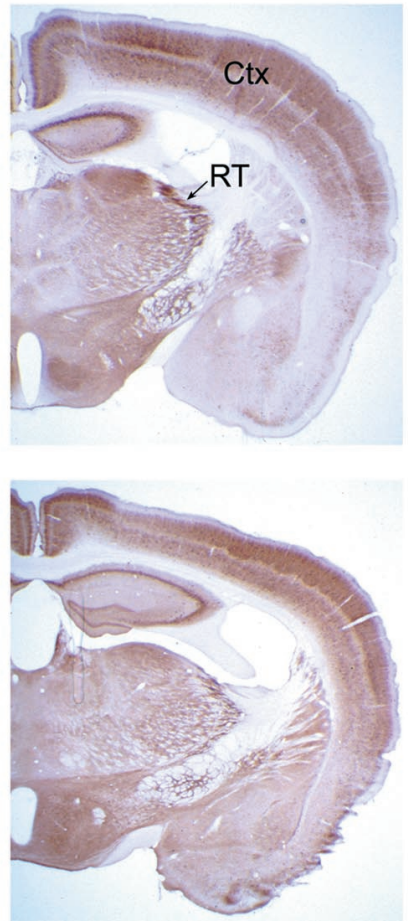

Kv3.2
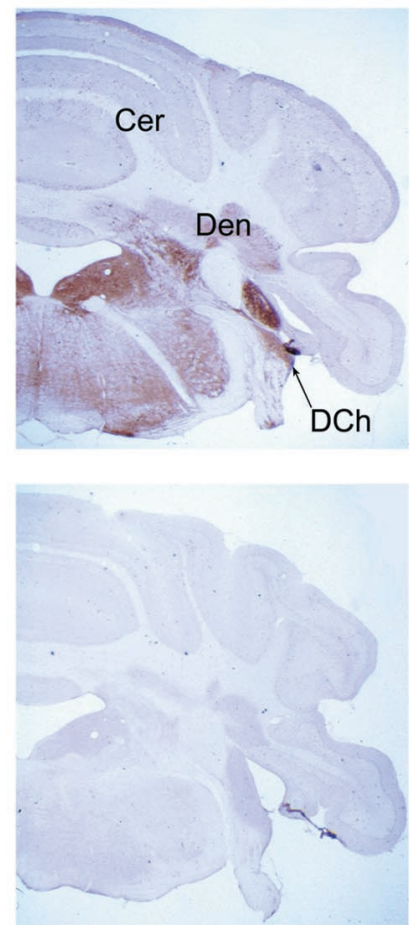

Kv3.1
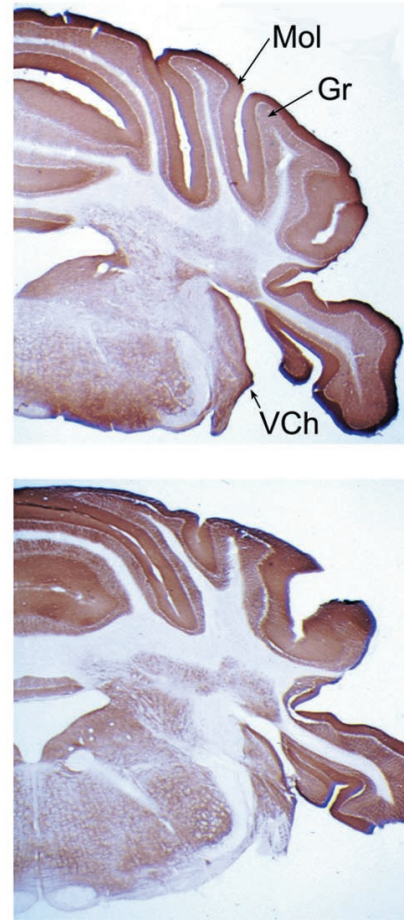

Figure 2. Normal distribution of Kv3.1 protein and lack of Kv3.2 protein in the Kv3.2 -/- mouse. Immunoperoxidase detection of Kv3.2 and Kv3.1 proteins in brain sections from: Top row Kv3.2 wild-type $(+/+)$; bottom row, Kv3.2 knock-out $(-/-)$ littermates. Sections were overexposed to emphasize the lack of Kv3.2 staining in knock-out mice. Kv3.2 products have a highly specific pattern of expression in brain and have not been detected outside the CNS (Rudy et al., 1999). In the brain, Kv3.2 proteins are prominently expressed in thalamocortical projections, the axons of the thalamic relay neurons in the dorsal thalamus (Moreno et al., 1995). The immunostaining of the collaterals of these axons in the reticular thalamic (RT) nucleus produces the labeling seen in this structure, and the staining of the thalamocortical terminals produces the labeled barrel structure seen in layer $I V$ of the neocortex $(\mathrm{Ctx})$. The staining of the hippocampus (Hip) and deep neocortical layers is produced by the prominent immunolabeling of the somas and axons of all PV-containing and a subset of somatostatin-containing GABAergic interneurons (Chow et al., 1999; Atzori et al., 2000). Kv3.2 proteins are also present in GABAergic neurons in other forebrain structures, including the caudate, basal forebrain, and globus pallidus $(G P)$. Kv3.2 proteins are found as well in yet to be identified neurons in the inferior colliculus, the nucleus of the lateral lemniscus, and dorsal cochlear $(D C h)$, trigeminal, deep-cerebellar (Den), and vestibular nuclei (Weiser et al., 1994; Moreno et al., 1995; Chow et al., 1999; Hernandez-Pineda et al., 1999; Atzori et al., 2000). Note the absence of Kv3.2 proteins and the normal distribution of Kv3.1 proteins in the knock-out mice. Cer, Cerebellum; Gr, granule cell layer of the cerebellar cortex; $\mathrm{Mol}$, molecular layer of the cerebellar cortex; $V B$, ventrobasal nucleus of the thalamus; $V C h$, ventral cochlear nucleus.

ences $(p>0.05)$ detected in overall total distance traveled in the open-field test, light-dark test, rotarod test, prepulse inhibition, startle habituation, conditioned fear, spatial learning, or hotplate test (see Materials and Methods). There was one significant difference in the open-field test. Knock-out mice had a significantly lower $(p<0.04)$ center-to-total distance ratio, which is an indicator of anxiety in the open field. However, there were no statistically significant differences in the light-dark exploration box (an independent test of anxiety), so one must be cautious about making too much of the anxiety phenotype in the open field. Future experiments will be needed to determine whether there is a possible anxiety phenotype by evaluating the mice in other assays of anxiety such as the elevated plus-maze.

Spontaneous, epileptic episodes lasting 5-40 sec and characterized by tonic-clonic convulsions have been observed in behaving $\mathrm{Kv} 3.2-/-$ mice $(n=14$ out of several hundred Kv3.2-deficient mice under similar manipulations) but never in wild-type littermates. These always occurred while the animals were being manipulated but could not be reliably provoked by routine handling or auditory or photic stimuli. The electrographic record during one of these spontaneous episodes is shown in Figure 3. Spontaneous epileptic episodes in the Kv3.2 -/- mice are rare, and usually there are none during typical studies with the mice. The waking background EEG activity in these mutants is unremarkable, and no abnormal patterns of spike-wave discharge were observed in particular. However, the seizures suggest cortical excitability increases in the Kv3.2 -/- mouse, a hypothesis that was supported by a series of experiments described later in this paper.

\section{Impaired fast spiking in cortical interneurons from Kv3.2 $-/-$ mice}

We used the Kv3.2 -/- mice to directly test the hypothesis that $\mathrm{K}^{+}$channels containing $\mathrm{Kv} 3$ proteins are required for sustained high-frequency firing in fast-spiking cortical interneurons. Because PV-containing cortical interneurons in the deep layers prominently express both Kv3.2 and Kv3.1 proteins (probably in heteromeric channels), whereas PV-containing neurons in superficial layers express mainly Kv3.1 subunits (Chow et al., 1999), we predicted that PV-containing neurons in the deep layers would be more affected in Kv3.2 - / - mice than neurons in superficial layers. We confirmed that the levels (data not shown) and distribution (Fig. 4) of PV immunoreactivity in the cortex were not affected in the Kv3.2 - - mouse.

The shape of action potentials and the repetitive firing properties of cells from knock-out and wild-type littermate mice in both superficial and deep cortical layers were compared using whole-cell recording methods from nonpyramidal neurons visualized by IRDIC optics in slices of somatosensory cortex. Nonpyramidal neurons in both knock-out and wild-type mice had different firing patterns that could be classified into three types, similar to those previously reported in rat and mouse neocortex: regular spiking (RS), low-threshold spiking (LTS), and fast spiking (FS) (Kawaguchi and Kubota, 1993, 1997; Cauli et al., 1997; Erisir et al., 1999; Gibson et al., 1999). Under our recording conditions, FS neurons were characterized by having short-duration action potentials and large, brief AHPs. In response to sustained current injection, they 


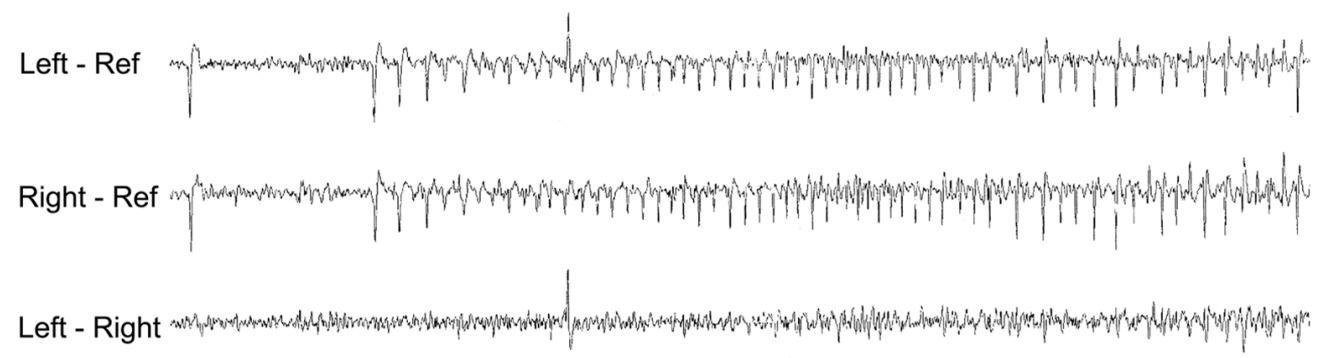

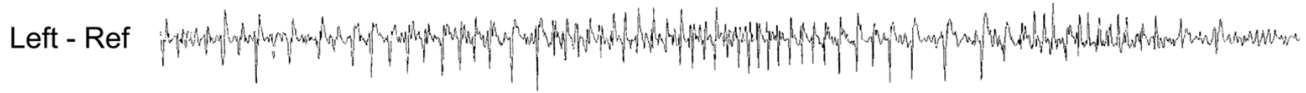

Figure 3. Electrographic pattern of a spontaneous seizure in a Kv3.2 -1mouse. Continuous EEG recording of a generalized tonic-clonic behavioral convulsive episode shows bilateral seizure activity arising shortly after a single interictal discharge. Abnormal synchronous activity increases in frequency for $\sim 40 \mathrm{sec}$ and ends abruptly with no postictal depression of the EEG.

Figure 4. Normal distribution of cortical PV immunoreactivity in Kv3.2-deficient mice. Immunoperoxidase detection of $\mathrm{PV}$ in Kv3.2 wild-type $(A-C)$ and knockout $(D-F)$ littermates. PV is localized in a subpopulation of neurons in the neocortex and hippocampus $(A, D)$. In the neocortex $(B, E), \mathrm{PV}$-positive neurons are scattered throughout all cortical layers. In neocortical interneurons in wild-type and knock-out animals $(C, F), \mathrm{PV}$ is present in multipolar neurons (also known as basket cells) and is expressed throughout the cell, including dendrites and axons. Pyramidal cells (some indicated by arrows) are not stained for PV but are surrounded by immunopositive puncta (the baskets), the terminal boutons from the GABAergic interneurons. Scale bar: $A, D, 1 \mathrm{~mm} ; B, E$, $250 \mu \mathrm{m} ; C, F, 50 \mu \mathrm{m}$.

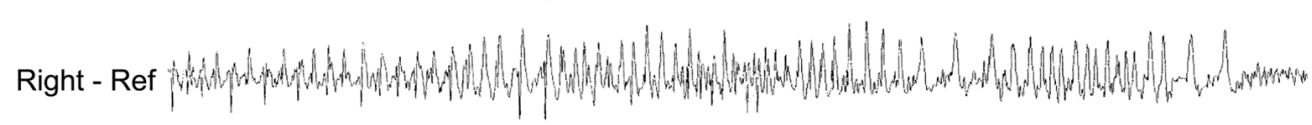

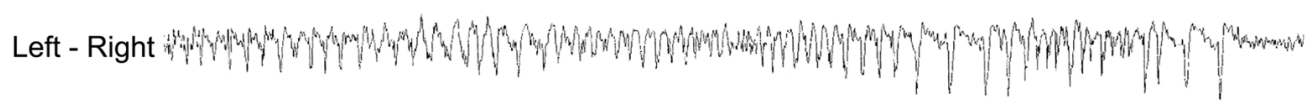
$1300 \mu \mathrm{V}$

$5 \mathrm{sec}$
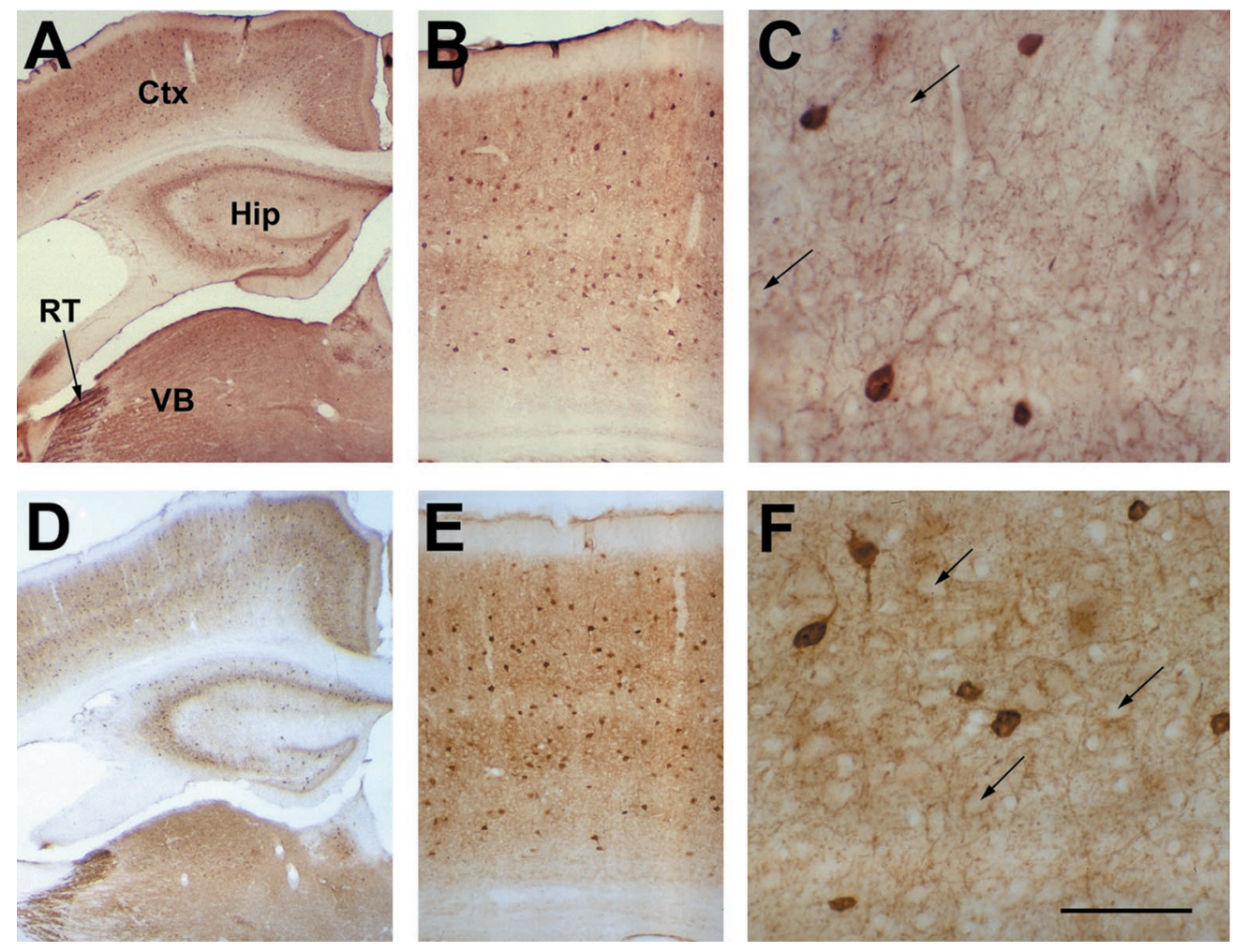

fired high-frequency spike trains with abrupt onset and little spike frequency adaptation. These neurons were easily distinguished from regular spiking neurons that sustained much lower maximum frequencies ( $\leq 50$ vs $>100$ spikes/sec) and adapted much more (mean rates at the end of a $600 \mathrm{msec}$ pulse were $\leq 40 \%$ of initial rates in RS neurons compared with $\geq 70 \%$ in FS cells). FS neurons could also be distinguished from LTS cells, which showed pronounced spike frequency adaptation (steady-state rates were, on average, $<40 \%$ of initial rates) and generated low-threshold spikes or spike bursts in response to depolarization from hyperpolarized potentials [as previously described in rat by Kawaguchi and Kubota (1993) and Gibson et al. (1999)]. FS neurons had firing thresholds 10-15 $\mathrm{mV}$ more positive than RS and LTS cells and had signifi- cantly lower input resistance than the other two types of cells $(133 \pm 6.2 \mathrm{M} \Omega, n=22$ for FS, compared with $222.1 \pm 22 \mathrm{M} \Omega, n=$ 52 for RS, and $349.7 \pm 30.2 \mathrm{M} \Omega, n=21$ for LTS cells) [similar to observations in rat by Kawaguchi and Kubota (1993)].

The action potential and repetitive firing characteristics of a typical multipolar, PV-positive, layer 5 neuron from a wild-type mouse are compared with those of a multipolar, PV-positive, layer 5 neuron from a knock-out littermate in Figures 5 and 6. The action potential from the knock-out mouse was broader (width at half maximum of $1.1 \mathrm{vs} 0.72 \mathrm{msec}$ ) (Fig. $5 A_{1}$ ) and had a slower maximum rate of repolarization (66 vs $110 \mathrm{mV} / \mathrm{msec}$ ) (Fig. $5 A_{2}$, dashed line) than the neuron from the wild-type littermate. In addition, the deceleration of the membrane potential as it entered into the 

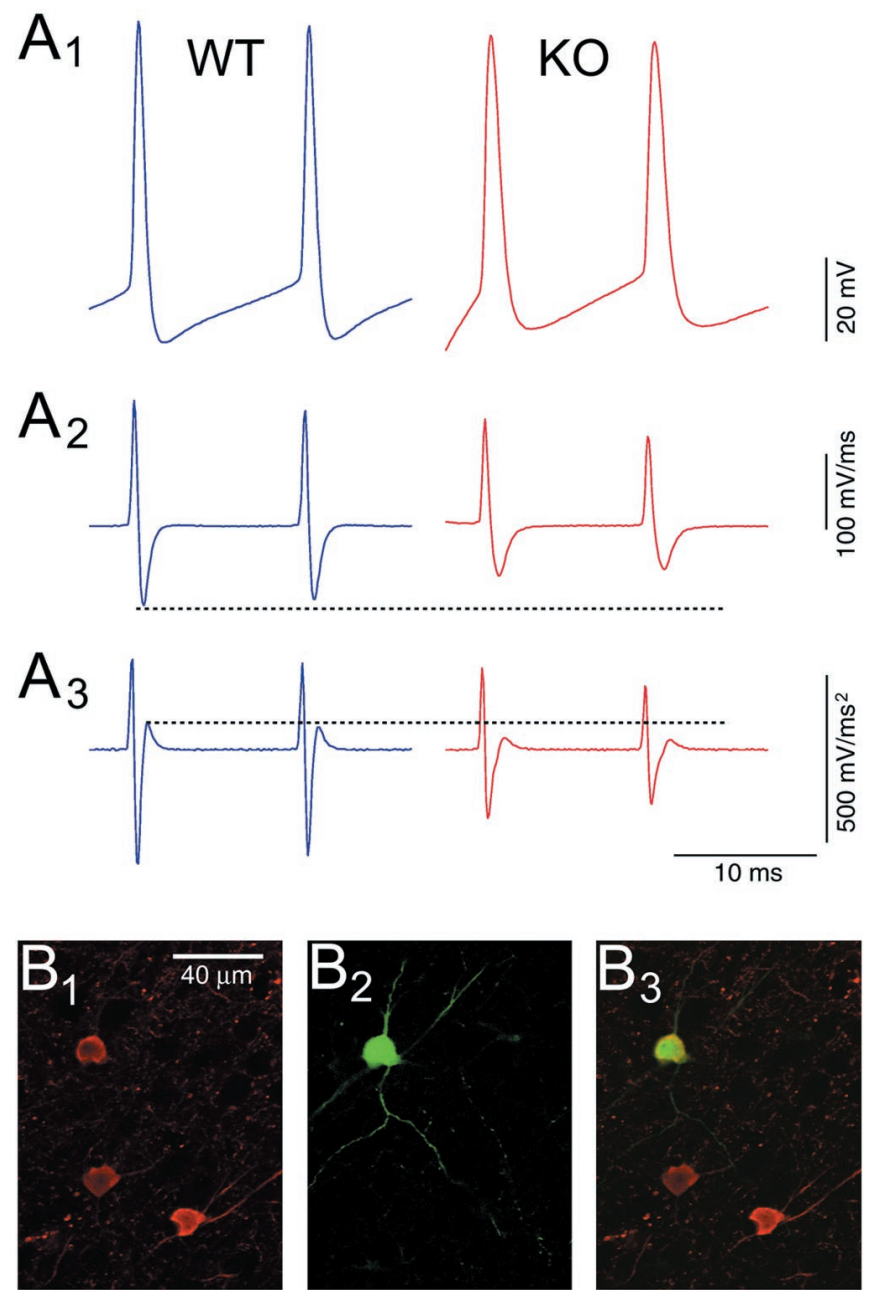

Figure 5. FS neurons from Kv3.2-deficient mice have broader action potentials with slower rates of repolarization. $A$, Representative action potentials from a PV-immunoreactive deep-layer neuron from a Kv3.2 wildtype $(W T)$ mouse are compared with the action potentials from a representative PV-immunoreactive deep-layer neuron from a Kv3.2 - /$(K O)$ mouse. Shown for each neuron are two action potentials $\left(A_{1}\right)$ and their first $\left(A_{2}\right)$ and second $\left(A_{3}\right)$ derivatives. The action potentials were wider (1.1 vs $0.72 \mathrm{msec}$ at half maximum), and their maximum rates of repolarization were smaller in the knock-outs (second peak in first derivative; dashed line in $A_{2}$ ). In addition, the peak deceleration of the membrane potential as it enters into the AHP (third peak in the second derivative; dashed line in $A_{3}$ ) was much smaller in the knock-out. $B$, The knock-out neuron whose data are shown in $A$ was biocytin-labeled $\left(B_{2}\right)$ and was immunoreactive for parvalbumin $\left(B_{1}\right.$; see also $B_{3}$, in which the superimposition of the images with the two chromophores is shown), indicating that it was an FS neuron. Data from this cell are also shown in Figure 6.

AHP was smaller in the Kv3.2 -/- neuron, suggesting that the repolarization current decays more slowly (Fig. $5 A_{3}$, dashed line). These and other differences in action potential shape are summarized in Table 1 and indicate that spike repolarization was impaired in the deep-layer FS neurons from knock-out animals. Despite these differences, the maximum rate of rise of the spike (for single spikes or the initial spike in a train) was similar in the neurons from the two genotypes (Table 1), indicating that the mechanisms responsible for initiating the action potential were unimpaired. To verify that recordings were made from PVcontaining neurons, slices were fixed and processed for PV immunohistochemistry after the recording and filling of neurons with biocytin (Du et al., 1996; Erisir et al., 1999). An example from a Kv3.2 - / - mouse is shown in Figure $5 B$. All of the FS cells that were scored for PV immunoreactivity (see details in Materials and Methods) were PV-positive ( $n=14$ from wild-type mice and 16 from knock-outs), and the inverse was also true; all of the neurons that were scored positive for PV had been classified as fast-spiking electrophysiologically.

Fast-spiking neurons from wild-type and knock-out mice also differed in their repetitive firing characteristics. Records from a typical PV-positive neuron in deep cortical layers of each genotype are shown in Figure 6. Both cells fired repetitively during steady depolarizations, and in both cases the steady-state firing rate increased as a function of injected current reaching near-saturation values before spike failure took place (Fig. 6D). However, the wild-type neuron was able to sustain higher steady-state firing frequencies (133 vs 66 spikes/sec) and showed significantly less firing frequency adaptation (mean firing rate at the end of a 600 msec pulse was $75 \%$ of initial rates for the wild-type cell and $46 \%$ for the cell from the Kv3.2 - /- mouse) than the neuron from the knock-out (Fig. 6A-C). Spike failure also occurred at much lower current strengths in the knock-out neuron than in the wild type (Fig. 6B,D).

These differences between wild-type and knock-out deep-layer neurons were reproducible and statistically different when neurons from a large number of mice of each genotype were compared (Fig. 7, Table 1). In scatter plots comparing steady-state firing frequency and firing frequency adaptation (Fig. $7 A$ ) or steady-state firing frequency and action potential width at half maximum (Fig. $7 B$ ), the cells from each genotype showed a different, although overlapping, distribution $(p<0.01$ for the firing rate; $p<0.02$ for the degree of adaptation; $p<0.001$ for the spike width; one-way ANOVA). Most of the neurons from the knock-out were in a cluster of cells with lower steady-state frequencies, higher spike frequency adaptation, and wider spikes. Yet, even in the knock-out mice, fast-spiking cells fired faster and adapted less than regular spiking (Fig. 7 $A$ ) or LTS (data not shown) neurons. However, some of the fastest firing neurons from the Kv3.2 -/- animals fired nearly as fast as the fastest firing neurons from the wild-type animals. This may be related to the different relative levels of Kv3.1 and Kv3.2 proteins in individual neurons, given that the expression of Kv3.1 remained unaffected in the Kv3.2 -/- animals. Support for this idea was obtained from experiments with low TEA concentrations described below.

Several parameters that help distinguish fast-spiking neurons from other interneurons in wild-type animals remain unchanged in the mutant mice (Fig. 7C, Table 1) and were therefore also useful to distinguish the neurons electrophysiologically. As in the case of neurons from wild-type mice (see above), FS neurons in knock-out animals had lower input resistance than RS and LTS cells (142 \pm 8.6 M $\Omega, n=29 ; 231.8 \pm 16.4 \mathrm{M} \Omega, n=52$; and $329.5 \pm 19.7 \mathrm{M} \Omega$, $n=21$, respectively), as well as higher firing thresholds (10-15 $\mathrm{mV})$. There usually was more spontaneous synaptic activity observed in records from FS neurons than from the other cell types. LTS cells could also be distinguished from RS and FS neurons in normal and knock-out animals by the presence of low-threshold spikes when depolarized from hyperpolarized potentials, as in normal animals (Kawaguchi and Kubota, 1993, 1997; Gibson et al., 1999).

There were no differences between knock-out and wild-type littermates in the firing properties of regular spiking neurons (Fig. $7 A$ ). Furthermore, in contrast to the large differences in action potential shape and repetitive firing properties of deep-layer FS neurons from wild-type and knock-out mice, no significant differences were observed when FS neurons in superficial layers were compared (Fig. 7D, Table 1).

\section{Low TEA concentrations eliminate the differences between wild-type and Kv3.2 -/- fast-spiking neurons}

The differences in the action potential and repetitive firing properties of fast-spiking neurons from wild-type and knock-out mice resemble the effects produced by application of low concentrations of TEA $(<1 \mathrm{~mm})$ to neurons from normal mice (Erisir et al., 1999). However, although low TEA concentrations also nearly completely blocked the AHP (Erisir et al., 1999), the AHPs in knock-out mice were on the average only $\sim 25 \%$ smaller than in wild-type mice 
Figure 6. Impaired high-frequency firing in $\mathrm{Kv} 3.2-/-$ mice. $A$, Repetitive firing of an FS PV-positive deep-layer neuron from a wild-type mouse in response to two current steps (375 and $975 \mathrm{pA}$ ). Firing frequency increases with increased depolarizing current, and there is very little firing frequency adaptation throughout the pulse. $B$, Repetitive firing of an FS PV-positive deep-layer neuron from a Kv3.2 -1mouse (same cell as in Fig. 5) in response to same current steps as in $A$. Firing frequency is much less than in the neuron from the wild-type mouse, and there is more firing frequency adaptation. There is spike failure during the largest current step. Also notice that the AHPs are faster in the neuron from the wild-type mouse. $C$, Instantaneous firing frequency plotted as a function of time from onset of the current pulse of $875 \mathrm{pA}$ for the knock-out and 975 for the wild-type mice. Notice that there is much more adaptation of the firing frequency in the knock-out than in the wild type. $D$, Steady-state firing frequency versus injected current. Firing frequency increases with current injection much more in the neuron from the wild-type than the neuron from the knock-out mouse, and spike failure occurs with lower current strengths (indicated by the last point shown). In both cases the steady-state firing frequency reaches a saturating (steadystate) value before failure.

C
A

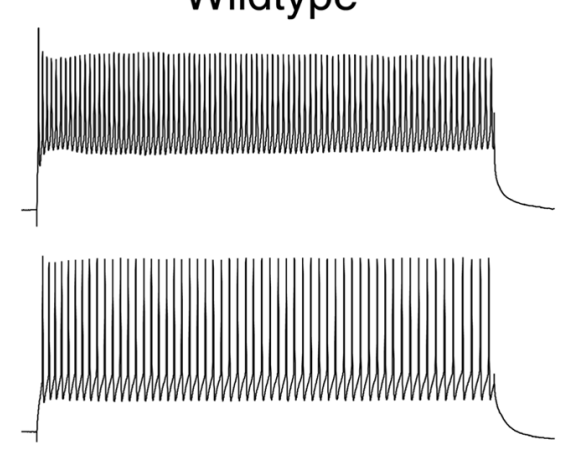

B
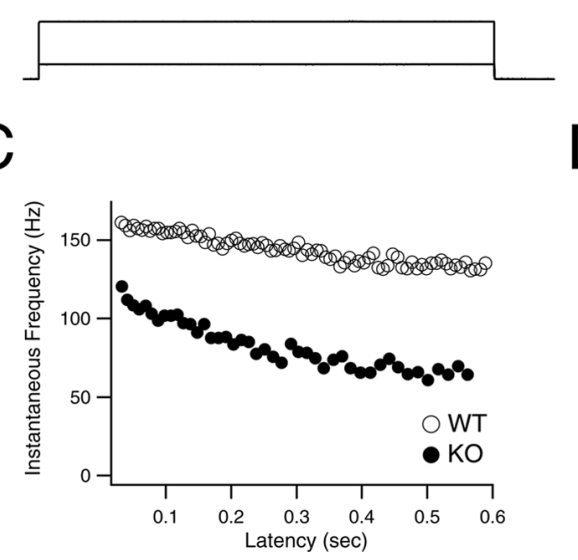

Knockout
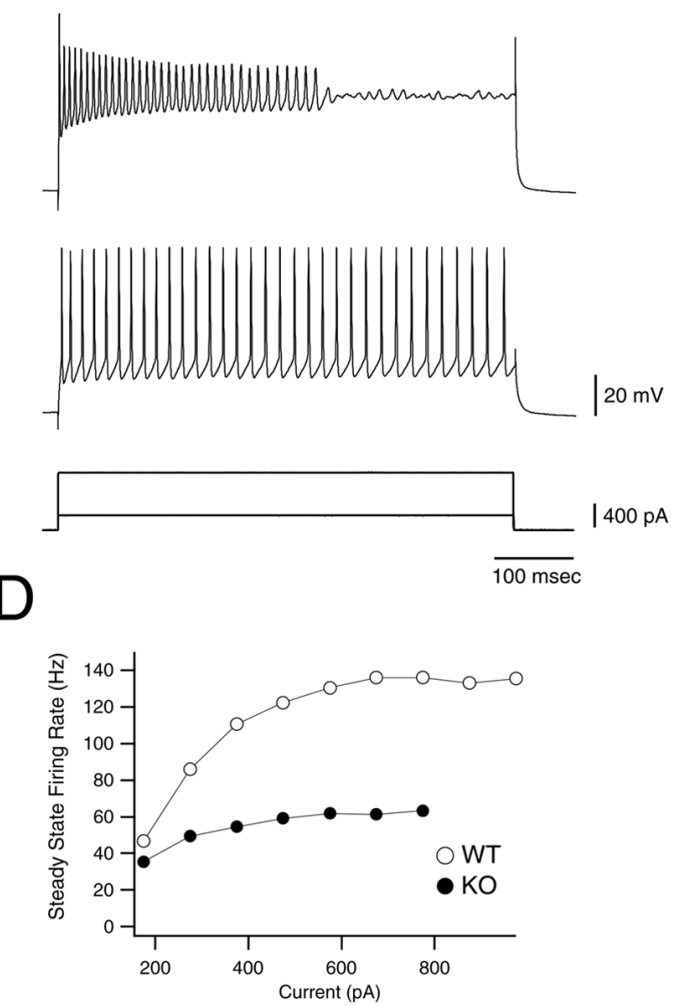

Table 1. Comparison of firing properties between wild-type and mutant FS cells in the neocortex

\begin{tabular}{|c|c|c|c|c|c|c|}
\hline & \multicolumn{3}{|c|}{ Layer V-VI } & \multicolumn{3}{|c|}{ Layer I-IV } \\
\hline & $p$ & $\begin{array}{l}\text { Wild-type } \\
n=20\end{array}$ & $\begin{array}{l}\text { Knock-out } \\
n=20\end{array}$ & $p$ & $\begin{array}{l}\text { Wild-type } \\
n=10\end{array}$ & $\begin{array}{l}\text { Knock-out } \\
n=10\end{array}$ \\
\hline Resting $V_{\mathrm{m}}(\mathrm{mV})$ & --- & $-64.45 \pm 0.54$ & $-63.60 \pm 0.57$ & --- & $-64.22 \pm 0.75$ & $-64.10 \pm 0.60$ \\
\hline$R_{\text {input }}(\mathrm{M} \Omega)$ & --- & $133.37 \pm 6.19$ & $142.42 \pm 8.61$ & --- & $153.50 \pm 17.92$ & $116.10 \pm 8.60$ \\
\hline Threshold (mV) & --- & $-38.35 \pm 0.59$ & $-38.81 \pm 1.02$ & --- & $-37.04 \pm 1.13$ & $-38.27 \pm 0.67$ \\
\hline $\begin{array}{l}\text { Maximum rising slo } \\
(\mathrm{mV} / \mathrm{msec})\end{array}$ & --- & $155.54 \pm 2.90$ & $149.65 \pm 8.04$ & --- & $151.65 \pm 6.33$ & $165.36 \pm 7.53$ \\
\hline $\begin{array}{l}\text { Maximum falling } \\
\text { slope }(\mathrm{mV} / \mathrm{msec})\end{array}$ & $* * *$ & $-84.07 \pm 1.84$ & $-61.11 \pm 5.07$ & --- & $-79.37 \pm 5.75$ & $-86.08 \pm 4.75$ \\
\hline $\begin{array}{l}\text { Spike width at half } \\
\text { amplitude (msec) }\end{array}$ & $* * *$ & $0.74 \pm 0.018$ & $0.94 \pm 0.038$ & --- & $0.78 \pm 0.031$ & $0.75 \pm 0.036$ \\
\hline AHP Amp (mV) & $* *$ & $16.14 \pm 0.68$ & $12.34 \pm 0.79$ & --- & $17.64 \pm 1.06$ & $15.86 \pm 0.69$ \\
\hline $\begin{array}{l}\text { AHP deceleration } \\
\left(\mathrm{mV} / \mathrm{msec}^{2}\right)\end{array}$ & $* * *$ & $133.88 \pm 5.71$ & $84.11 \pm 7.34$ & --- & $130.00 \pm 8.63$ & $135.96 \pm 12.49$ \\
\hline SS firing rate $(\mathrm{Hz})$ & $*$ & $152.11 \pm 7.04$ & $116.63 \pm 10.21$ & --- & $134.47 \pm 7.52$ & $155.21 \pm 13.35$ \\
\hline $\begin{array}{l}\text { SS firing rate/initial } \\
\text { frequency }\end{array}$ & $* *$ & $0.85 \pm 0.018$ & $0.71 \pm 0.031$ & --- & $0.80 \pm 0.023$ & $0.83 \pm 0.035$ \\
\hline
\end{tabular}

FS cells are organized by the cortical layer in which they were found. Spike width, AHP, and slope measurements are from single action potentials. $V_{\mathrm{m}}$, Membrane potential; $R_{\text {input }}$, input resistance of the cell; Amp, amplitude; SS, steady state. $p$ values determined by Student's $t$ test. ${ }^{*} p<0.01 ;{ }^{* *} p<0.001 ;{ }^{* * *} p<0.0001$; dashed lines indicate nonsignificance $(p>0.05)$.

(Table 1). Moreover, although submillimolar concentrations of TEA affect the magnitude but not significantly the kinetics of the AHP (Erisir et al., 1999), we found that the kinetics of the AHP was different in Kv3.2-deficient and wild-type animals (Fig. $\left.5 A_{1}, A_{3}\right)$. The fast AHP characteristic of fast-spiking neurons from wild-type mice was replaced by a slower AHP in fast-spiking neurons from Kv3.2 - /- mice (Fig. 5A) (Fig. 6, compare $A, B$ ). We hypothesize that the slow AHP in FS neurons from Kv3.2 -/mice is generated by the increased activation of an unidentified $\mathrm{K}^{+}$ conductance (perhaps mediated by $\mathrm{Ca}^{2+}$-activated $\mathrm{K}^{+}$channels), which deactivates at rates slower than those of Kv3 channels. There is increased activation of this conductance in Kv3.2-deficient mice because of the increase in the duration of the action potential. We would further like to suggest that this is not seen when TEA is used to block Kv3 channels because the drug also blocks this unidentified $\mathrm{K}^{+}$conductance. Consistent with this idea, low TEA concentrations blocked the slow AHP in neurons from knock-out mice (Fig. 8).

Other than these differential effects on the AHP, all of the effects of the Kv3.2 -/- mutation on the spike and repetitive firing properties of deep-layer fast-spiking neurons resembled the effects of a partial block of Kv3 channels with TEA $(\sim 0.2 \mathrm{~mm})$ on wildtype FS neurons (Erisir et al., 1999). We expected the mutation to 

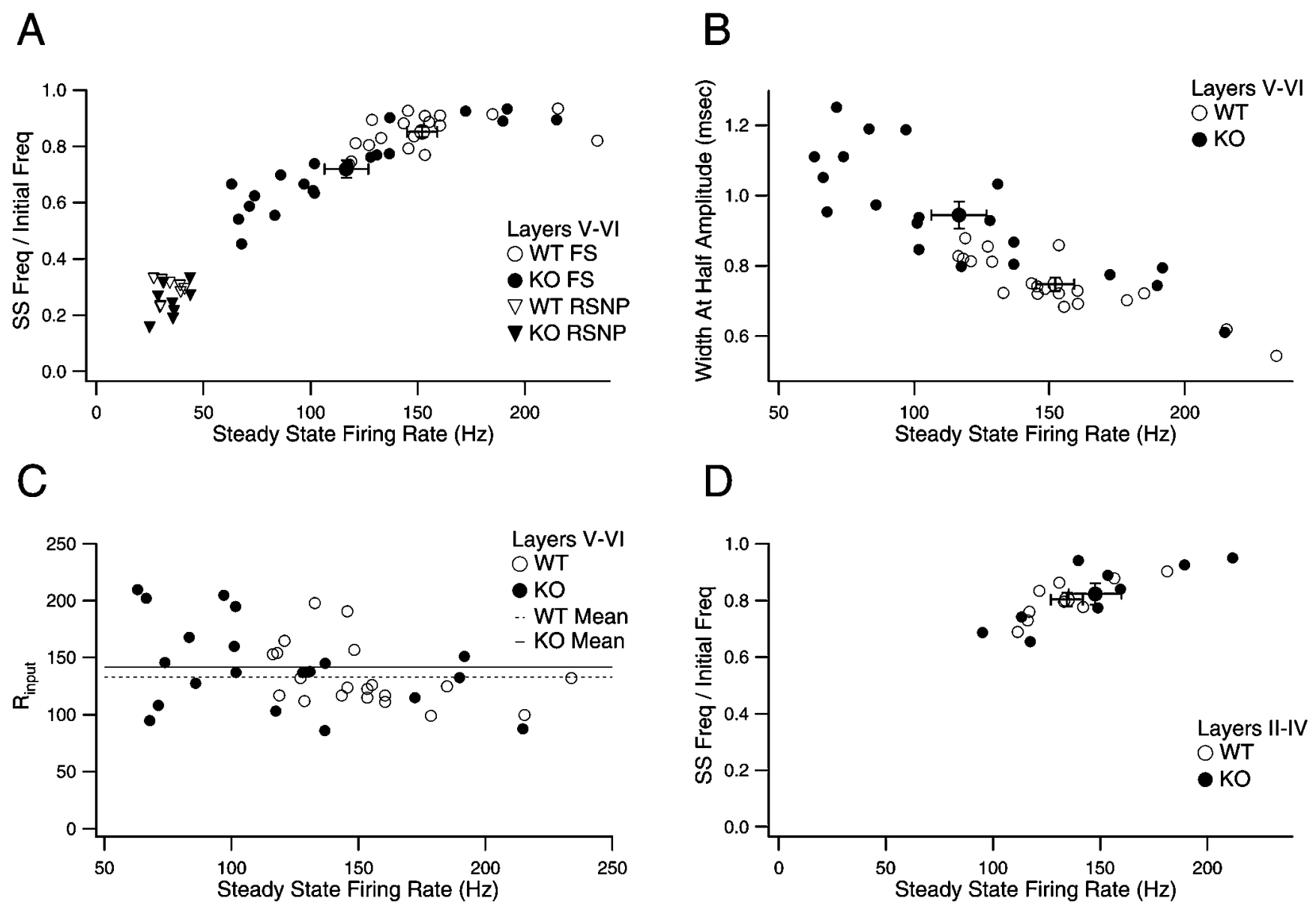

Figure 7. Disruption of the Kv3.2 gene affects the action potential duration and fast-spiking properties (but not the input resistance) of FS interneurons from deep cortical layers but not from superficial layers. The fraction of the initial firing frequency remaining at the end of a $600 \mathrm{msec}$ depolarization $(A)$, the width at half amplitude $(B)$, and the input resistance $(C)$ of FS layer V-VI neurons from wild-type (open symbols) and knock-out ( filled symbols) mice are plotted against the maximum steady-state firing rate of each cell. Parameters from deep-layer regular spiking nonpyramidal (RSNP) neurons of both genotypes are included in $A$ for comparison. Mean values for each parameter are indicated by the symbol with the error bars that indicate the SEM. The values from knock-out neurons clustered at lower maximum firing rates $(A, B)$, increased firing frequency adaptation $(A)$, and longer action potential duration $(B)$. However, there was no difference in the input resistance of FS neurons from wild-type and knock-out animals $(C)$. Also notice the quasi-linear relationship between steady-state firing rate and firing frequency adaptation $(A)$ or spike width $(B)$ in both wild-type and knock-out mice, indicating that these parameters depend on common underlying factors. $D$, Same as $A$ for layer II-III neurons from knock-out and wild-type mice, illustrating the lack of effect of the mutation on superficial layer FS neurons. Similarly, no differences were detected in action potential duration (Table 1).

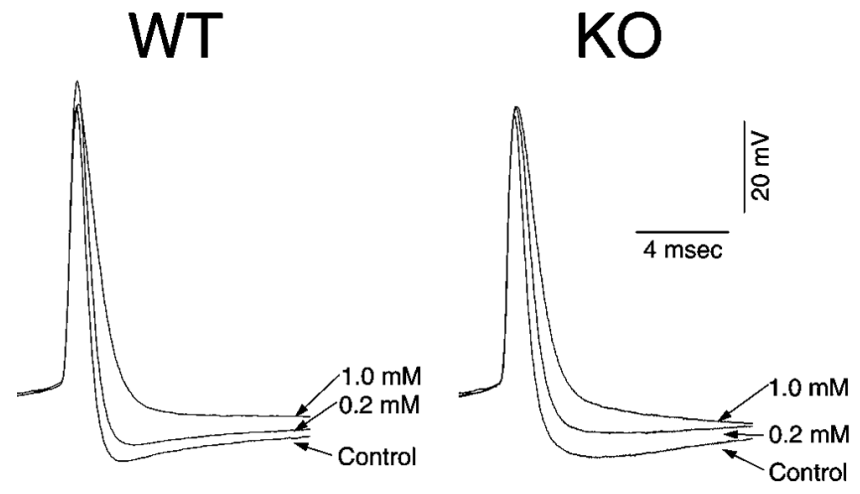

Figure 8. Low TEA concentrations block the AHP in FS neurons from wild-type $(W T)$ and knock-out $(K O)$ mice. The AHP is slower in the FS neuron from the Kv3.2 - - mouse. However, low TEA concentrations block the AHP nearly completely in both cases.

be equivalent to a partial block of Kv3 channels because FS neurons in the Kv3.2 - /- mice still express normal levels of Kv3.1 proteins (Figs. 1, 2), and Kv3.1 and Kv3.2 proteins express similar currents in heterologous expression systems (Hernandez-Pineda et al., 1999; Rudy et al., 1999). To test this hypothesis, we compared the effects of TEA on the spike width, steady-state firing rate, and degree of adaptation of fast-spiking neurons from wild-type and knock-out mice. The values of these parameters in FS neurons from knock-out animals in the absence of the channel blocker were close to those in wild-type animals in the presence of submillimolar concentrations of TEA. For example, the spike width of deep-layer FS neurons from Kv3.2-deficient mice $(0.94 \pm 0.04 \mathrm{msec}, n=20)$ was comparable with the spike width of wild-type mice in $0.2 \mathrm{~mm}$ TEA $(0.95 \pm 0.03 \mathrm{msec}, n=17)$. Similarly, the steady-state firing frequency and firing frequency adaptation of deep-layer FS neurons from $\mathrm{Kv} 3.2-/-$ mice $(116.6 \pm 10.2$ spikes per second, $n=20$; and $0.68 \pm 0.03, n=20$, respectively) were close to those for wild-type neurons in $\leq 0.2 \mathrm{mM}$ TEA $(92.9 \pm 2.9, n=16$; and $0.62 \pm$ 0.04, $n=15$, in 0.2 mM TEA) (Fig. 9). Furthermore, although TEA still had effects on spike width and repetitive firing properties of FS neurons from knock-out animals, the effects were smaller than those observed in neurons from wild-type animals (Fig. 9). In 1.0 mM TEA, a drug concentration expected to block $\geq 80 \%$ of the total Kv3 channels, knock-out and wild-type neurons had similar properties (e.g., $63 \pm 6$ spikes/sec, $n=15$; and $55 \pm 3$ spikes/sec, $n=18$, for the steady-state firing rate of wild-type and knock-out FS neurons, respectively, in $1 \mathrm{~mm}$ TEA) (Fig. 9C). This would be expected if the mutation and the drug (at concentrations of $\leq 1 \mathrm{~mm}$ ) are acting, for the most part, on the same conductance. These data are also consistent with the notion that we are recording from similar neurons in the two types of animals and that, other than the 

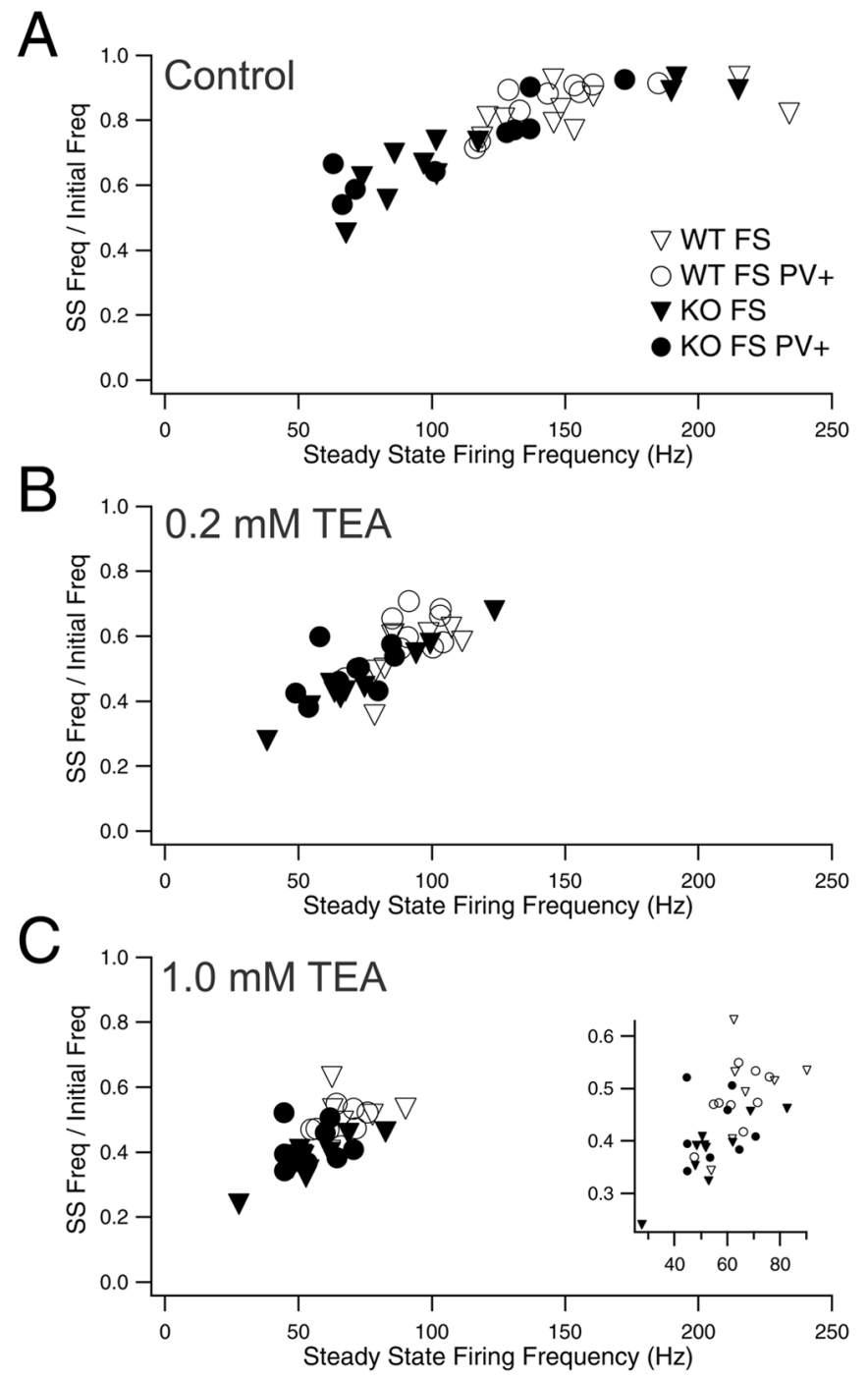

Figure 9. Low TEA concentrations affect the firing properties of FS neurons from wild-type mice more than those from knock-out mice. The steady-state firing frequency and the preservation of the initial firing frequency during a $600 \mathrm{msec}$ pulse are plotted for a number of deep-layer FS neurons in Kv3.2 - /- mice ( filled symbols) and wild-type littermates (open symbols $)$ in the absence of TEA $(A)$, and in the presence of $0.2(B)$ and 1 mM $(C)$ TEA. An amplified view of the data in $C$ is shown in the insert at the right. These neurons are a subset of the population of neurons shown in Figure $7 A-C$. Different symbols (as indicated in $A$ ) have been used for the FS neurons for which we were able to establish the PV immunoreactivity. Note that $0.2 \mathrm{~mm}$ TEA shifts more the values of the neurons from wild-type than knock-out mice and that, in the presence of $1 \mathrm{mM}$ TEA, FS neurons from wild-type and Kv3.2-deficient mice have similar properties. Similar results were obtained in plots of action potential duration (half width) and steady-state firing frequency (data not shown).

lack of the mutated channel proteins, the cells have not changed significantly in active conductances or other membrane properties. Moreover, these results also suggest that the dispersion in steadystate firing frequency values between different FS neurons might be the result of differences in the number of active Kv3 channels. Because Kv3 channel activity can be modulated by neurotransmitters and second messengers (Moreno et al., 1995; Atzori et al., 2000), different cortical neurons could have different proportions of active channels depending on having been recent targets of these modulators.

\section{FS neurons can repetitively fire spike doublets at $40 \mathrm{~Hz}$, an ability that requires Kv3 channels}

Under certain physiological conditions, fast-spiking neurons may not undergo long, steady depolarizations such as those used in the previous experiments. For example, it has been shown in both the neocortex and the hippocampus (Traub et al., 1996, 1999; Steriade et al., 1998) that, when stimulated, fast-spiking neurons generate fast rhythmic $(\sim 40 \mathrm{~Hz})$ spike bursts. The bursts consist of two (spike doublets) to three spikes with intraburst frequencies that are similar to the steady-state frequencies observed during long, steady depolarizations $(100-200 \mathrm{~Hz}$ at room temperature; $300-400 \mathrm{~Hz}$ at $37^{\circ} \mathrm{C}$ ). We asked whether the ability to generate such rhythmic bursts repetitively is impaired in FS neurons from the Kv3.2 -/mice. Cortical neurons were stimulated repetitively with brief depolarizations that generated one or more spikes per stimulus, repeated at various frequencies. We focus on the results at $40 \mathrm{~Hz}$, the characteristic frequency observed in the EEG during periods of brain activation (Bouyer et al., 1981; Llinas and Ribary, 1993; Murthy and Fetz, 1996a,b; Steriade et al., 1996). In wild-type mice, both regular-spiking and fast-spiking GABAergic interneurons in both superficial and deep cortical layers could follow $40 \mathrm{~Hz}$ stimuli that generated a single spike per stimulus for periods up to $1 \mathrm{~min}$ (the longest tested; data not shown). However, only fast-spiking neurons could follow larger stimuli that generated a spike doublet without failing (Fig. 10). In contrast, deep-layer, fast-spiking neurons from knock-out mice failed in their ability to fire spike doublets repetitively much more rapidly than did neurons from wild-type animals (Fig. $10 A, B$ ). In fact, in Kv3.2 -/- mice, during the first stimulus, the second spike was already smaller than the first spike, and it got smaller, slower, and more delayed with subsequent depolarizations (Fig. 10A), suggesting a reduction in the available $\mathrm{Na}^{+}$current. This is consistent with the hypothesis that Kv3 channels facilitate fast spiking by increasing $\mathrm{Na}^{+}$channel recovery from inactivation (Erisir et al., 1999). This behavior was similar to that observed after application of low concentrations of TEA on deep-layer FS neurons from wild-type mice (data not shown).

\section{Increased cortical excitability in the Kv3.2 -/- mouse}

The cellular analysis showed that the ability of fast-spiking interneurons to fire at high frequencies for long durations or repetitively is impaired in Kv3.2 -/- mice. The knock-out mice are thus useful to test hypotheses of the function of these neurons and the significance of fast spiking in their performance. The presence of sporadic epileptic seizures in Kv3.2-deficient mice suggests that the mice have an increased susceptibility to seizures. Here we present a series of observations that provide further evidence of increased cortical excitability and susceptibility to seizures in the Kv3.2 -/mouse.

The first experiment consisted of recording spontaneous EEG from cortex and thalamus in ketamine-xylazine anesthetized Kv3.2 $-/-$ and wild-type mice. Results were obtained with multisite extracellular and field potential recordings using arrays of highimpedance tungsten electrodes. As shown in Figure $11 A$, wild-type mice $(n=21)$ showed the characteristic slow rhythm observed during natural slow-wave sleep and during ketamine-xylazine anesthesia in other species (Steriade et al., 1993a; Contreras and Steriade, 1995). In wild-type mice, the slow rhythm was characterized by recurring sequences at $<1 \mathrm{~Hz}$ of depth-negative followed by depth-positive waves in the EEG, which occurred in synchrony with the corresponding thalamic territory. Such sequences correspond intracellularly to neuronal depolarization and hyperpolarization, respectively (Steriade et al., 1993a; Contreras and Steriade, $1995)$. The EEG of the Kv3.2 - /- mice $(n=18)$ showed, superimposed on the underlying slow rhythm, spontaneous highamplitude sharp potentials, lasting from 30 to $100 \mathrm{msec}$ and with the same polarity as the slow oscillation (depth-negative and surface-positive). Such sharp potentials pervaded throughout all phases of the slow oscillation and produced a very irregular slow rhythm (Fig. 11B). Nevertheless, the slow rhythm is clearly present, suggesting that the cortical synchronization responsible for this rhythm still occurs in the knock-out. The "spikiness" of the slow rhythm in Kv3.2-deficient mice, illustrated with the example in Figure $11 B$, is the most characteristic effect of the mutation that we have observed until now. All Kv3.2 - / - mice tested showed similar irregularities on the EEG, which we have never seen in wild-type 


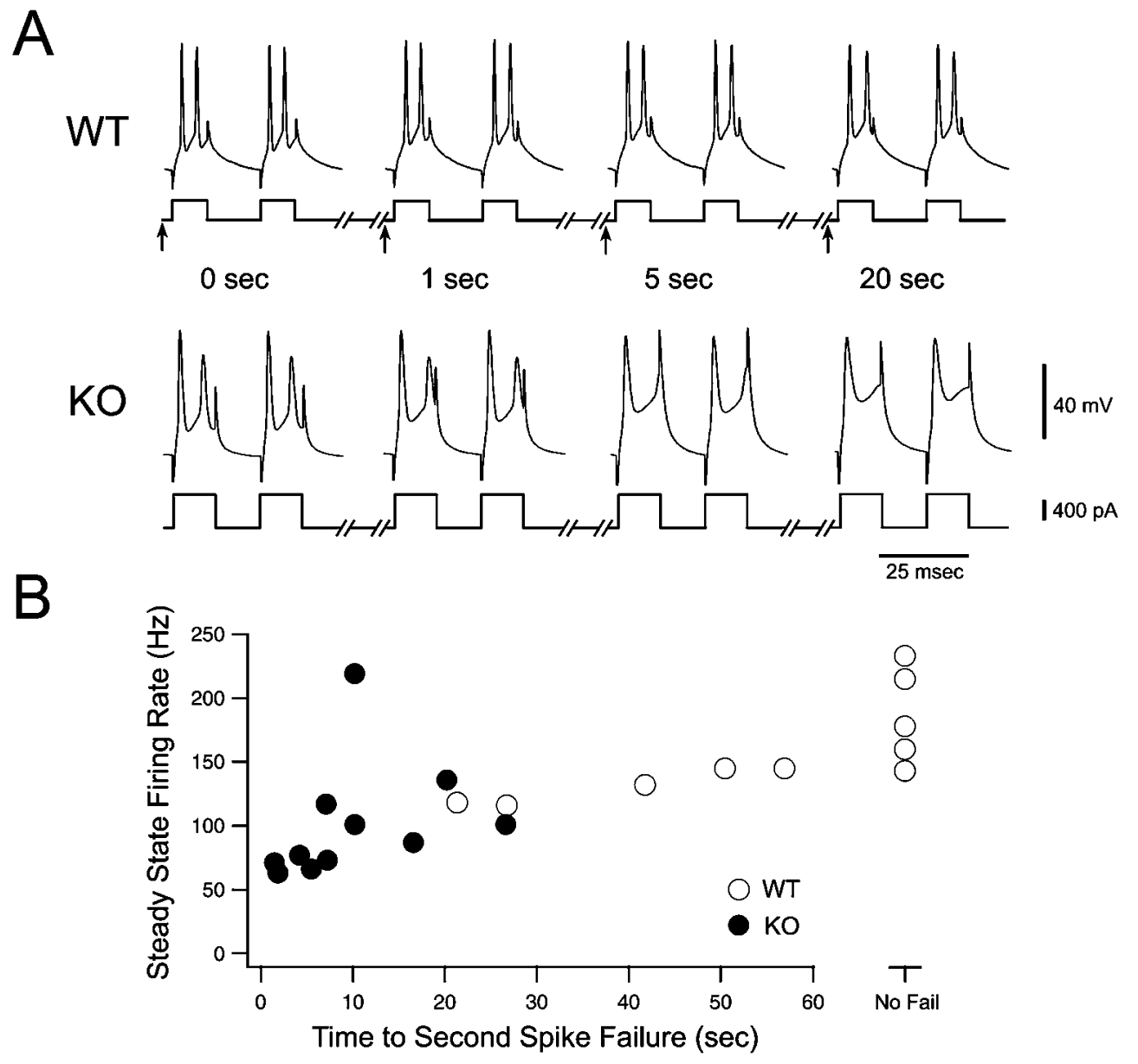

Figure 10. Deep-layer FS neurons from wild-type, but not from Kv3.2-deficient, mice can repetitively fire action potential doublets for long periods. $A$, FS neurons from wild-type $(W T)$ and $\mathrm{Kv} 3.2-/-(K O)$ mice were stimulated repetitively at $40 \mathrm{~Hz}$ with brief depolarizing current pulses that generated a spike doublet (for a total duration of $1 \mathrm{~min}$ ). Shown are the pulses and voltage responses for the first two stimuli and the first two after 1, 5, and $20 \mathrm{sec}$ of continuous stimulation. The wild-type neuron never failed to respond with a spike doublet. In contrast, the knock-out neuron failed to generate a spike doublet rapidly after the onset of the stimulation. Note that, in the knock-out, the second spike is smaller than the first spike from the first current pulse, and it becomes smaller, slower, and more delayed with subsequent depolarizations until the cell fails to generate a second spike. $B$, Summary of the results of this test applied to 11 knock-out neurons and 10 wild-type neurons. The plot indicates the maximum firing rate versus the time at which the cell failed to produce a second spike for FS neurons from wild-type (open symbols) and Kv3.2-deficient mice (filled symbols). In approximately half of the wild-type neurons, the cell continued to fire spike doublets for the duration of the experiment $(1 \mathrm{~min})$. The other half failed at times considerably longer $(40 \pm 6.9 \mathrm{sec})$ than those that produced failure in neurons from the Kv3.2deficient mice $(10 \pm 2.4 \mathrm{sec})$. littermates or in mice from commercial sources. The high degree of spatiotemporal synchrony of the slow rhythm is achieved by massive reentrant corticocortical circuits, as shown by the absence of effects of massive ipsilateral thalamectomy followed by sectioning of the callosum (Steriade et al., 1993b). We propose that the sharp potentials in the Kv3.2 - /- mouse reflect a poor local control of the strong synchronized corticocortical inputs that reach the cortex during the slow oscillations.

In the course of the previous experiments, we found that seizures were prevalent in Kv3.2 -/- mice under ketamine-xylazine anesthesia. Under these conditions, most (12 of 18) Kv3.2 -/- mice, but not their wild-type littermates ( 0 of 21 ), showed electrographic seizures that occurred spontaneously (typically every 10-20 min) (Fig. 12A). Similar seizures were easily induced in Kv3.2 - /-mice ( 12 of 12 mice tested) by electrical stimulation of the thalamus (Fig. $12 B)$. In contrast, we were never able to evoke seizures in wild-type animals $(n=19)$, even with stimuli that were 10 times stronger or longer in duration (and in a variety of patterns) than those required to evoke seizures in knock-out mice. Both spontaneous and evoked seizures were often associated with motor manifestations that varied from small jerks of the limbs and movements of the whiskers to full convulsions. In principle, these seizures could result from increased thalamic input into the cortex or from reduced cortical control in Kv3.2-deficient mice. This is an important consideration, given the prominent expression of Kv3.2 in thalamic relay neurons and thalamocortical projections (Fig. 2) (Rudy et al., 1992; Weiser et al., 1994; Moreno et al., 1995). However, the failure to induce seizures when large doses of bicuculline are injected into the thalamus (Steriade and Contreras, 1998) shows that the feedforward and feedback inhibitory mechanisms of the cortex are capable of handling the entrance into the cortex of thalamic stimuli of increased magnitude. Therefore, the presence of thalamic-induced seizures in the Kv3.2 -/- mouse is likely to result from increased cortical excitability.
The last set of experiments consisted of testing seizure susceptibility to chemical convulsants in vivo. Kv3.2 -/- mice were more sensitive to the convulsant $\mathrm{PTZ}$, a $\mathrm{GABA}_{\mathrm{A}}$ receptor antagonist. When challenged with a single dose of PTZ (50 mg/kg), Kv3.2 -/mice showed more severe responses than wild-type littermates (Fig. 13A). For example, at this dose, $52 \%$ of Kv3.2 $-/-$ mice $(n=$ $23)$ compared with $16 \%$ of wild types $(n=19)$ developed severe stage 4 tonic-clonic convulsions associated with death. Similarly, the delay between drug application and the first evidence of epileptic activity was significantly shorter in the knock-out mice (Fig. 13B).

Together, the data provide strong evidence that mice deficient in Kv3.2 subunits have susceptibility to seizures probably reflecting an increase in cortical excitability. Because Kv3.2 proteins are expressed in inhibitory but not in excitatory neurons in the cortex (Chow et al., 1999), and assuming that compensatory changes in other cortical elements have not taken place, the inferred increase in cortical excitability most likely arises from impaired cortical inhibition. Deficits in cortical inhibition may occur in the Kv3.2 $-/-$ mouse if the fast-spiking ability of GABAergic interneurons is necessary to achieve proper levels of inhibition (see Discussion). This increased cortical excitability is likely to contribute to the spontaneous seizures observed in awake animals.

\section{DISCUSSION}

\section{Kv3 channels and high frequency firing}

Three (Kv3.1-Kv3.3) of the four Kv3 genes are prominently expressed in brain tissue and show different but overlapping patterns of expression (Perney et al., 1992; Rudy et al., 1992; Vega-Saenz de Miera et al., 1994; Weiser et al., 1994). Many, if not most, of the neuronal populations expressing these genes fire spikes at high frequency. This correlation led to the suggestion that Kv3 channels may play an important role in high-frequency firing (see introduc- 


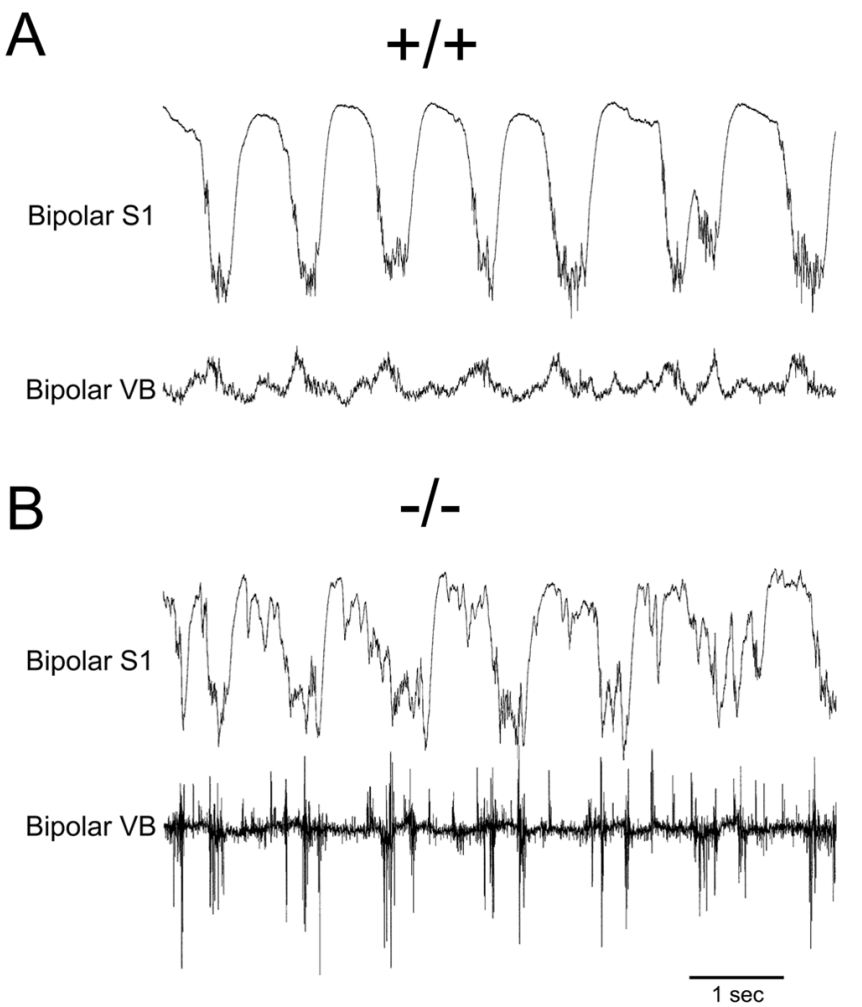

Figure 11. Distortions in the cortical EEG in the Kv3.2 -/- mouse. Bipolar EEG from the $\mathrm{S} 1$ cortex and the ventrobasal nucleus of the thalamus (VB) in a wild-type $(A)$ and a knock-out $(B)$ mouse. Both EEGs show a predominant slow rhythm $(<1 \mathrm{~Hz})$ typical of ketamine-xylazine anesthesia. Whereas the EEG of the normal mouse shows a regular pattern in synchrony with the thalamus, the EEG of the knock-out mouse is pervaded by high-amplitude, short-lasting waves in all phases of the slow oscillation. Such sharp waves occur in synchrony with burst firing in the thalamic recording. Because we observed no significant electrophysiological differences in the thalamus of wild-type and Kv3.2 - / - mice (data not shown), we ascribed the generation of burst firing in thalamus to an increased corticothalamic drive probably caused by increased firing of cortical cells during the sharp potentials.

tory remarks). Experiments using the $\mathrm{K}^{+}$channel blockers TEA and 4-AP, at concentrations that block Kv3 channels in heterologous expression systems (Grissmer et al., 1994; Coetzee et al., 1999; Rudy et al., 1999), and Kv3-like currents in native neurons (Du et al., 1996; Wang et al., 1998; Erisir et al., 1999; HernandezPineda et al., 1999) support the idea that Kv3 channels play a dominant role in repolarizing the action potential of expressing neurons and are necessary to maintain high-frequency firing (Du et al., 1996; Massengill et al., 1997; Martina et al., 1998; Wang et al., 1998; Erisir et al., 1999). However, the possibility that these drugs are also blocking other types of $\mathrm{K}^{+}$channels has been difficult to eliminate.

In this study, we used the genetic elimination of the Kv3.2 gene, which is prominently expressed in deep-layer FS neurons in the neocortex, to test directly the role of $\mathrm{Kv} 3$ genes in fast spiking. The results show that fast spiking is impaired in neocortical deep-layer FS neurons but not in superficial layer FS neurons in which Kv3.2 is weakly expressed. These results provide strong, independent evidence that Kv3 channels play a critical role in enabling highfrequency firing in FS neurons. Together with data showing that the PKA-dependent modulation of the firing frequency of FS interneurons in the hippocampus is absent in Kv3.2 $-/-$ mice (Atzori et al., 2000), the experiments described here provide the most direct evidence for a critical role of $\mathrm{Kv} 3$ channels in sustained or repetitive high-frequency firing.

The ability of Kv3 channels to facilitate sustained or repetitive high-frequency firing is a direct consequence of the special properties of these channels that distinguish them from other voltagegated $\mathrm{K}^{+}$channels. (1) By activating at very depolarized potentials, the cell can use large numbers of Kv3 channels to produce fastspike repolarization and a large AHP with minimum effects on input resistance, threshold, or rise time, thus keeping action potentials brief without compromising action potential generation. (2) By keeping action potentials brief, Kv3 channels minimize the inactivation of the $\mathrm{Na}^{+}$conductance during the spike. (3) By generating a large AHP, Kv3 channels accelerate recovery from the $\mathrm{Na}^{+}$channel inactivation that did take place during the spike. (4) The brief duration of the AHP (produced by the fast deactivation of Kv3 channels) restores high-input resistance quickly. The increase in the number of $\mathrm{Na}^{+}$channels that have recovered from inactivation and the fast termination of the AHP minimize the duration of the refractory period, allowing the cell to reach firing threshold sooner than in the absence of Kv3 channels (Sekirnjak et al., 1997; Erisir et al., 1999).

The effects of blocking Kv3 channels become stronger during long trains or repetitive activity because there is accumulation of $\mathrm{Na}^{+}$channel inactivation resulting from the repeated activation of the channels. The larger increase in spike rise time during repetitive activity in Kv3.2-deficient mice (Figs. $5 A_{1}, A_{2}, 10$ ) supports this view. The results with Kv3.2-deficient mice also suggest that the increased activation of slower $\mathrm{K}^{+}$conductances active during the $\mathrm{AHP}$, produced by the increase in action potential duration, may
Figure 12. Seizures in the ketamine-xylazine anesthetized Kv3.2 - / - mouse. $A$ and $B$ represent data from two different animals. EEG was recorded from the depth of the primary somatosensory cortex (SI). The seizure in $A$ occurred spontaneously. The seizure in $B$ was triggered by high-frequency stimulation ( 7 short trains of $100 \mathrm{~Hz}$ repeated at $\sim 10 \mathrm{~Hz}$ ) delivered to the ventrobasal nucleus of the thalamus (VB stim). Both spontaneous and evoked seizures were initiated abruptly by a paroxysmal depolarizing shift $(P D S)$ and consisted of runs of $5-7 \mathrm{~Hz}$ low-amplitude waves followed by higher amplitude waves usually at $<1 \mathrm{~Hz}$. Seizures also terminated abruptly and were followed by a variable period $(10-30 \mathrm{sec})$ of postictal depression with flat EEG. The background activity preceding seizures was like that seen in Figure $11 B$. Note the change in gain during the record shown in $B$. The gain in $A$ had been changed earlier and was 10 times smaller before the seizure.

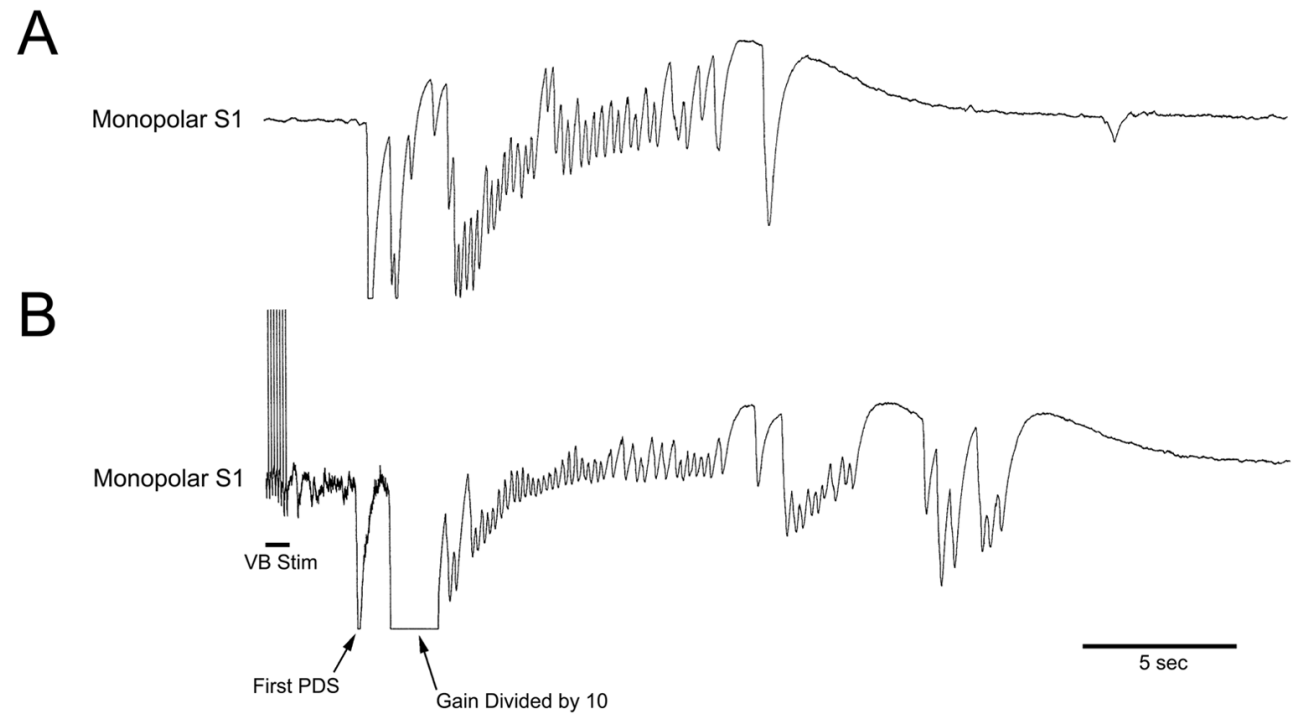



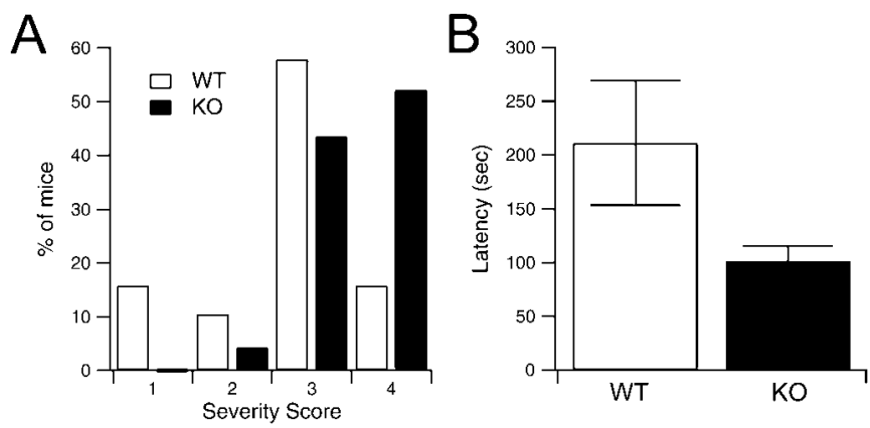

Figure 13. Susceptibility of Kv3.2-deficient mice to PTZ-induced seizures. $A$, The maximum response of wild-type $(W T ; n=19)$ and knock-out $(K O$; $n=23$ ) mice after a single injection of $50 \mathrm{mg} / \mathrm{kg}$ PTZ intraperitoneally was scored as follows: 1 , only isolated twitches; 2 , only partial or focal seizures (stage 3, see Materials and Methods); 3, generalized clonic seizures; and 4, large tonic-clonic epileptic seizures. Knock-out mice tend to progress to more severe stages than wild-type littermates. $p<0.01$ (Mann-Whitney rank sum test). $B$, Latency to first seizure. Plotted is the time from the PTZ injection to the first sign of seizure. The latency was shorter for the knock-out mice. $p<0.02$, Student's $t$ test.

also contribute to reducing firing frequency and increasing firing frequency adaptation after Kv3 channel removal.

Evidence that Kv3 channels are necessary for sustained or repetitive high-frequency firing has now been obtained for FS neurons in the neocortex and hippocampus (Martina et al., 1998; Erisir et al., 1999; Atzori et al., 2000; this study), for neurons in the medial vestibular nucleus (MVN) (S. du Lac and C. Sekirnjak, unpublished observations) and the medial nucleus of the trapezoid body (MNTB) in the auditory brainstem (Wang et al., 1998). Kv3 gene products are found in many other neurons capable of highfrequency firing (Weiser et al., 1994), suggesting a similar role in these neurons. Although it appears that Kv3 channels are necessary for sustained or repetitive high-frequency firing in many (if not all) high-frequency firing neurons, their presence is clearly not sufficient. The effects on excitability of the Kv3 channels will depend on the other conductances active on the cell and their precise localization in the neuron. In fact, the three cell types (FS interneurons in the neocortex and hippocampus, neurons in the MNTB, and neurons in the MVN) for which a role of Kv3 channels in highfrequency firing has been suggested have different firing properties. Both FS interneurons and MVN neurons (du Lac and Lisberger, 1995; du Lac, 1996) fire long, high-frequency spike trains in response to steady depolarizations. However, FS interneurons produce long, high-frequency spike trains abruptly, and the steadystate firing frequency saturates as a function of injected current (as in the examples shown here). In contrast, MVN neurons are spontaneously active, and the relationship between injected current and firing frequency is nearly linear (du Lac and Lisberger, 1995; du Lac, 1996). The presence of low voltage-activating or persistent $\mathrm{Na}^{+}$channels and differences in other conductances probably account for these differences in firing properties.

On the other hand, the MNTB neurons produce one or, at most, two action potentials independently of the duration or strength of the depolarization, probably because depolarization activates large, low voltage-activating " $\mathrm{D}$ "-type $\mathrm{K}^{+}$currents that limit repetitive activity (Brew and Forsythe, 1995). However, these neurons can fire action potentials entrained to very high-frequency inputs $(>600 \mathrm{~Hz})$, the property which appears to depend on Kv3 (probably Kv3.1 and Kv3.3) channels (Wang et al., 1998).

Kv3 channels are an excellent example of how the specialized properties of certain channels contribute to functional specificity. This helps to explain the biological significance of $\mathrm{K}^{+}$channel diversity as a key factor contributing to the diversity of the electrophysiological properties of neurons and to the specificity of neuromodulator actions (Adams and Galvan, 1986; Llinas, 1988; Rudy, 1988; Baxter and Byrne, 1991; Hille, 1992).

\section{Increased cortical excitability in the Kv3.2 -/- mouse}

Several observations indicate that Kv3.2-deficient mice have increased cortical excitability. Increased excitability, resulting in increased susceptibility to seizures, if not a full epileptic behavior, has also been observed in two other $\mathrm{K}^{+}$channel knock-out mice lines: Kv1.1 (Smart et al., 1998) and one of the G-protein-gated inward rectifier $\mathrm{K}^{+}$channel genes (GIRK2) (Signorini et al., 1997). Moreover, mutations in the $\mathrm{K}^{+}$channel genes KCNQ2 and $\mathrm{KCNQ3}$, subunits of $\mathrm{M}$-type $\mathrm{K}^{+}$channels, have been found in humans with benign familial neonatal convulsions (Charlier et al., 1998; Singh et al., 1998). A strong association between increased excitability and $\mathrm{K}^{+}$channel dysfunction may not seem surprising. $\mathrm{K}^{+}$channels typically suppress and limit cell excitability by competing with depolarizing currents, and thus, reduced $\mathrm{K}^{+}$channel expression is expected to generate hyperexcitability. Indeed, 4-AP and other $\mathrm{K}^{+}$channel blockers are often used as convulsants in experimental animals (Rutecki et al., 1987; Velluti et al., 1987).

However, it is very likely that the underlying mechanism responsible for the increased cortical excitability of Kv3.2-deficient mice is different from that producing the hyperexcitability phenotypes in the other examples. $\mathrm{K}^{+}$channels containing Kv1.1, GIRK2, and KCNQ2 and KCNQ3 subunits operate close to the resting potential and act as breaks dampening the effects of depolarizing inputs. Moreover, these channels are prominently expressed in excitatory neurons in neocortex, hippocampus, and many other brain areas. Hyperexcitability of these cells, resulting from suppressing these channels, is likely to underlie the hyperexcitability behavior ( $\mathrm{Si}$ gnorini et al., 1997; Smart et al., 1998). However, in the neocortex and hippocampus, Kv3.2 is only expressed by inhibitory neurons (Chow et al., 1999; Atzori et al., 2000). The defects in the function of these cells are likely to be key contributors to the observed increases in cortical excitability, although this remains to be conclusively demonstrated.

Hyperexcitability of these interneurons should produce increased cortical inhibition and therefore suppression of hyperexcitable phenotypes, contrary to what we see in the Kv3.2 -/- mouse. The solution to this apparent paradox lies in the unique role of Kv3 channels in neuronal excitability as illustrated by the results obtained with the Kv3.2-deficient mouse, which suggest that suppression of this $\mathrm{K}^{+}$channel results in impaired cellular firing instead of hyperexcitability. Kv3 channels are not active anywhere near threshold potentials, and therefore their removal is not expected to affect much the responsiveness to synaptic inputs. As shown here and in previous pharmacological studies (Du et al., 1996; Massengill et al., 1997; Erisir et al., 1999), suppression of Kv3 channels produces broadening of the action potential. This could increase GABA release from these cells, which should result in increased cortical inhibition. On the other hand, cortical inhibition might be reduced if the ability to sustain repetitive firing at high frequencies is even more important in determining inhibitory levels. Our data suggest that this is the case and that impaired fast spiking decreases the performance of the inhibitory circuits in the cortex. This view is consistent with observations that FS neurons fire long, highfrequency trains or repetitive high-frequency bursts of action potentials in response to physiological stimuli (Kawaguchi and Kubota, 1993; Benardo, 1994; Zhu and Connors, 1999). Future studies on the performance of inhibitory synaptic transmission in knockout and wild-type animals should provide further tests of this view.

The fact that a single type of $\mathrm{K}^{+}$channel plays a dominant role in enabling high-frequency firing has allowed us to generate mice lines in which this property is impaired in selective neuronal populations. Preliminary experiments show cellular changes similar to those described here on FS neurons in superficial cortical layers in Kv3.1-deficient mice (Ho et al., 1997), and larger effects resembling those produced by complete Kv3 channel block (and throughout all layers of the cortex) are expected on mice deficient in both genes. GABAergic interneurons are thought to play important roles in many cortical functions. These mice lines will be interesting models to test hypotheses on the role of GABAergic interneurons in these functions. For example, preliminary observations in 
the hippocampus revealed a decrease in high-frequency oscillations in $\mathrm{Kv} 3.2-/-$ mice, suggesting impaired synchronization (Atzori et al., 2000), one of the key roles attributed to cortical GABAergic interneurons.

\section{REFERENCES}

Adams PR, Galvan M (1986) Voltage-dependent currents of vertebrate neurons and their role in membrane excitability. Adv Neurol 44:137-170.

Agmon A, Connors BW (1991) Thalamocortical responses of mouse somatosensory (barrel) cortex in vitro. Neuroscience 41:365-379.

Amitai Y, Connors BW (1995) Intrinsic physiology and morphology of single neurons in neocortex. In: Cereb cortex (Jones EG, Diamond IT, eds), pp 299-331. New York: Plenum.

Atzori M, Lau D, Phillips-Tansey E, Chow A, Ozaita A, Rudy B, McBain CJ (2000) Histamine (H2) receptor-dependent PKA phosphorylation of Kv3.2 modulates fast spiking in hippocampal interneurons. Nat Neurosci 3:791-798.

Babila T, Moscucci A, Wang H, Weaver FE, Koren G (1994) Assembly of mammalian voltage-gated potassium channels: evidence for an importan role of the first transmembrane segment. Neuron [Erratum (1996) 16: 1061] 12:615-626.

Baxter DA, Byrne JH (1991) Ionic conductance mechanisms contributing to the electrophysiological properties of neurons. Curr Opin Neurobiol $1: 105-112$.

Benardo LS (1994) Separate activation of fast and slow inhibitory postsynaptic potentials in rat neocortex in vitro. J Physiol (Lond) 476:203-215.

Bouyer JJ, Montaron MF, Rougeul A (1981) Fast fronto-parietal rhythms during combined focused attentive behaviour and immobility in cat: cortical and thalamic localizations. Electroencephalogr Clin Neurophysiol 51:244-252.

Brew HM, Forsythe ID (1995) Two voltage-dependent $\mathrm{K}^{+}$conductances with complementary functions in postsynaptic integration at a central auditory synapse. J Neurosci 15:8011-8022.

Cauli B, Audinat E, Lambolez B, Angulo MC, Ropert N, Tsuzuki K, Hestrin S, Rossier J (1997) Molecular and physiological diversity of cortical nonpyramidal cells. J Neurosci 17:3894-3906.

Celio MR (1986) Parvalbumin in most gamma-aminobutyric acidcontaining neurons of the rat cerebral cortex. Science 231:995-997.

Charlier C, Singh NA, Ryan SG, Lewis TB, Reus BE, Leach RJ, Leppert M (1998) A pore mutation in a novel KQT-like potassium channel gene in an idiopathic epilepsy family. Nat Genet 18:53-55.

Chomczynski P, Sacchi N (1987) Single-step method of RNA isolation by acid guanidinium thiocyanate-phenol-chloroform extraction. Anal Biochem 162:156-159.

Chow A, Erisir A, Farb C, Nadal MS, Ozaita A, Lau D, Welker E, Rudy B (1999) $\mathrm{K}^{+}$channel expression distinguishes subpopulations of parvalbumin- and somatostatin-containing neocortical interneurons. J Neurosci 19:9332-9345.

Coetzee WA, Amarillo Y, Chiu J, Chow A, Lau D, McCormack T, Moreno H, Nadal MS, Ozaita A, Pountney D, Saganich M, Vega-Saenz de Miera E, Rudy B (1999) Molecular diversity of K+ channels. Ann NY Acad Sci 868:233-285.

Contreras D, Steriade M (1995) Cellular basis of EEG slow rhythms: a study of dynamic corticothalamic relationships. J Neurosci 15:604-622.

Du J, Zhang L, Weiser M, Rudy B, McBain CJ (1996) Developmental expression and functional characterization of the potassium-channel subunit Kv3.1b in parvalbumin-containing interneurons of the rat hippocampus. J Neurosci 16:506-518.

du Lac S (1996) Candidate cellular mechanisms of vestibulo-ocular reflex plasticity. Ann NY Acad Sci 781:489-498.

du Lac S, Lisberger SG (1995) Membrane and firing properties of avian medial vestibular nucleus neurons in vitro. J Comp Physiol [A] 176:641-651.

Erisir A, Lau D, Rudy B, Leonard CS (1999) Function of specific K(+) channels in sustained high-frequency firing of fast-spiking neocortical interneurons. J Neurophysiol 82:2476-2489.

Fairen A, Defelipe J, Regidor J (1984) Nonpyramidal neurons: general account. In: Cereb cortex (Jones E, Peters A, eds), pp 201-245. New York: Plenum.

Franklin K, Paxinos G (1997) The mouse brain in stereotaxic coordinates. San Diego: Academic.

Freund TF, Buzsaki G (1996) Interneurons of the hippocampus. Hippocampus 6:347-470.

Galarreta M, Hestrin S (1999) A network of fast-spiking cells in the neocortex connected by electrical synapses. Nature 402:72-75.

Gibson JR, Beierlein M, Connors BW (1999) Two networks of electrically coupled inhibitory neurons in neocortex. Nature 402:75-79.

Gilbert CD (1993) Circuitry, architecture, and functional dynamics of visual cortex. Cereb Cortex 3:373-386.

Gonchar Y, Burkhalter A (1997) Three distinct families of GABAergic neurons in rat visual cortex. Cereb Cortex 7:347-358.

Goslin K, Banker G (1991) Rat hippocampal neurons in low density culture. In: Culturing nerve cells (Banker G, Goslin K, eds), pp 251-282. Cambridge, MA: MIT

Grissmer S, Nguyen AN, Aiyar J, Hanson DC, Mather RJ, Gutman GA, Karmilowicz MJ, Auperin DD, Chandy KG (1994) Pharmacological characterization of five cloned voltage-gated $\mathrm{K}+$ channels, types Kv1.1, 1.2, 1.3, 1.5, and 3.1, stably expressed in mammalian cell lines. Mol Pharmacol 45:1227-1234.

Gupta A, Wang Y, Markram H (2000) Organizing principles for a diversity of GABAergic interneurons and synapses in the neocortex. Science 287:273-278.

Hartshorne RP, Catterall WA (1984) The sodium channel from rat brain. Purification and subunit composition. J Biol Chem 259:1667-1675.

Hendry SH, Jones EG, Emson PC, Lawson DE, Heizmann CW, Streit P (1989) Two classes of cortical GABA neurons defined by differential calcium binding protein immunoreactivities. Exp Brain Res 76:467-472.

Hernandez-Pineda R, Chow A, Amarillo Y, Moreno H, Saganich M, de Miera EV, Hernandez-Cruz A, Rudy B (1999) Kv3.1-Kv3.2 channels underlie a high-voltage-activating component of the delayed rectifier $\mathrm{K}+$ current in projecting neurons from the globus pallidus. J Neurophysiol 82:1512-1528.

Hille B (1992) Ionic channels of excitable membranes. Sunderland, MA: Sinauer.

Ho CS, Grange RW, Joho RH (1997) Pleiotropic effects of a disrupted K+ channel gene: reduced body weight, impaired motor skill and muscle contraction, but no seizures. Proc Natl Acad Sci USA 94:1533-1538.

Jefferys JG, Traub RD, Whittington MA (1996) Neuronal networks for induced " $40 \mathrm{~Hz}$ " rhythms. Trends Neurosci 19:202-208.

Jones EG (1975) Varieties and distribution of non-pyramidal cells in the somatosensory cortex of the squirrel monkey. J Comp Neurol 160:205-368.

Jones EG (1993) GABAergic neurons and their role in cortical plasticity in primates. Cereb Cortex 3:361-372.

Joyner AL (2000) Gene targeting: a practical approach. New York: Oxford.

Kawaguchi Y, Kubota Y (1993) Correlation of physiological subgroupings of nonpyramidal cells with parvalbumin- and calbindinD28kimmunoreactive neurons in layer $\mathrm{V}$ of rat frontal cortex. J Neurophysiol 70:387-396.

Kawaguchi Y, Kubota Y (1997) GABAergic cell subtypes and their synaptic connections in rat frontal cortex. Cereb Cortex 7:476-486.

Keller A (1995) Synaptic organization of the barrel cortex. In: Cereb cortex (Jones EG, Diamond IT, eds), pp 221-262. New York: Plenum.

Kimber WL, Hsieh P, Hirotsune S, Yuva-Paylor L, Sutherland HF, Chen A, Ruiz-Lozano P, Hoogstraten-Miller SL, Chien KR, Paylor R, Scambler PJ, Wynshaw-Boris A (1999) Deletion of $150 \mathrm{~kb}$ in the minimal DiGeorge/velocardiofacial syndrome critical region in mouse. Hum Mol Genet 8:2229-2237.

Lenz S, Perney TM, Qin Y, Robbins E, Chesselet MF (1994) GABA-ergic interneurons of the striatum express the Shaw-like potassium channel Kv3.1. Synapse 18:55-66.

Li M, Jan YN, Jan LY (1992) Specification of subunit assembly by the hydrophilic amino-terminal domain of the Shaker potassium channel. Science 257:1225-1230.

Llinas R, Ribary U (1993) Coherent 40-Hz oscillation characterizes dream state in humans. Proc Natl Acad Sci USA 90:2078-2081.

Llinas RR (1988) The intrinsic electrophysiological properties of mammalian neurons: insights into central nervous system function. Science 242:1654-1664.

Martina M, Schultz JH, Ehmke H, Monyer H, Jonas P (1998) Functional and molecular differences between voltage-gated $\mathrm{K}+$ channels of fastspiking interneurons and pyramidal neurons of rat hippocampus. J Neurosci 18:8111-8125.

Massengill JL, Smith MA, Son DI, O’Dowd DK (1997) Differential expression of K4-AP currents and Kv3.1 potassium channel transcripts in cortical neurons that develop distinct firing phenotypes. J Neurosci 17:3136-3147.

McCormack K, Tanouye MA, Iverson LE, Lin JW, Ramaswami M, McCormack T, Campanelli JT, Mathew MK, Rudy B (1991) A role for hydrophobic residues in the voltage-dependent gating of Shaker K+ channels. Proc Natl Acad Sci USA 88:2931-2935.

McCormack T, Vega-Saenz de Miera EC, and Rudy B (1990) Molecular cloning of a member of a third class of Shaker-family $\mathrm{K}+$ channel genes in mammals. Proc Natl Acad Sci USA [Erratum (1991) 88:4060] 87:5227-5231.

McCormick DA, Connors BW, Lighthall JW, Prince DA (1985) Comparative electrophysiology of pyramidal and sparsely spiny stellate neurons of the neocortex. J Neurophysiol 54:782-806.

Moreno H, Kentros C, Bueno E, Weiser M, Hernandez A, Vega-Saenz de Miera, E, Ponce A, Thornhill W, Rudy B (1995) Thalamocortical projections have a $\mathrm{K}^{+}$channel that is phosphorylated and modulated by cAMP-dependent protein kinase. J Neurosci 15:5486-5501.

Murthy VN, Fetz EE (1996a) Oscillatory activity in sensorimotor cortex of awake monkeys: synchronization of local field potentials and relation to behavior. J Neurophysiol 76:3949-3967.

Murthy VN, Fetz EE (1996b) Synchronization of neurons during local field potential oscillations in sensorimotor cortex of awake monkeys. J Neurophysiol 76:3968-3982.

Paylor R, Nguyen M, Crawley JN, Patrick J, Beaudet A, Orr-Urtreger A (1998) Alpha7 nicotinic receptor subunits are not necessary for hippocampal-dependent learning or sensorimotor gating: a behavioral characterization of Acra7-deficient mice. Learn Mem 5:302-316. 
Peier AM, McIlwain KL, Kenneson A, Warren ST, Paylor R, Nelson DL (2000) (Over)correction of FMR1 deficiency with YAC transgenics: behavioral and physical features. Hum Mol Genet 9:1145-1159.

Perney TM, Marshall J, Martin KA, Hockfield S, Kaczmarek LK (1992) Expression of the mRNAs for the Kv3.1 potassium channel gene in the adult and developing rat brain. J Neurophysiol 68:756-766.

Ribera AB, Pacioretty LM, Taylor RS (1996) Probing molecular identity of native single potassium channels by overexpression of dominant negative subunits. Neuropharmacology 35:1007-1016.

Robertson E (1987) Teratocarcinomas and embryonic stem cells: a practical approach. Washington, DC: Oxford.

Rudy B (1988) Diversity and ubiquity of K channels. Neuroscience 25:729-749.

Rudy B, Hoger JH, Lester HA, Davidson N (1988) At least two mRNA species contribute to the properties of rat brain A-type potassium channels expressed in Xenopus oocytes. Neuron 1:649-658.

Rudy B, Kentros C, Weiser M, Fruhling D, Serodio P, Vega-Saenz de Miera E, Ellisman MH, Pollock JA, Baker H (1992) Region-specific expression of a $\mathrm{K}+$ channel gene in brain. Proc Natl Acad Sci USA 89:4603-4607.

Rudy B, Chow A, Lau D, Amarillo Y, Ozaita A, Saganich M, Moreno H, Nadal MS, Hernandez-Pineda R, Hernandez-Cruz A, Erisir A, Leonard C, Vega-Saenz de Miera E (1999) Contributions of Kv3 channels to neuronal excitability. Ann NY Acad Sci 868:304-343.

Rutecki PA, Lebeda FJ, Johnston D (1987) 4-Aminopyridine produces epileptiform activity in hippocampus and enhances synaptic excitation and inhibition. J Neurophysiol 57:1911-1924.

Sekirnjak C, Martone ME, Weiser M, Deerinck T, Bueno E, Rudy B, Ellisman M (1997) Subcellular localization of the K+ channel subunit Kv3.1b in selected rat CNS neurons. Brain Res 766:173-187.

Shen NV, Pfaffinger PJ (1995) Molecular recognition and assembly sequences involved in the subfamily-specific assembly of voltage-gated $\mathrm{K}+$ channel subunit proteins. Neuron 14:625-633.

Signorini S, Liao YJ, Duncan SA, Jan LY, Stoffel M (1997) Normal cerebellar development but susceptibility to seizures in mice lacking G-protein-coupled, inwardly rectifying K+ channel GIRK2. Proc Natl Acad Sci USA 94:923-927.

Singer W, Gray CM (1995) Visual feature integration and the temporal correlation hypothesis. Annu Rev Neurosci 18:555-586.

Singh NA, Charlier C, Stauffer D, DuPont BR, Leach RJ, Melis R, Ronen GM, Bjerre I, Quattlebaum T, Murphy JV, McHarg ML, Gagnon D, Rosales TO, Peiffer A, Anderson VE, Leppert M (1998) A novel potassium channel gene, KCNQ2, is mutated in an inherited epilepsy of newborns. Nat Genet 18:25-29.

Smart SL, Lopantsev V, Zhang CL, Robbins CA, Wang H, Chiu SY, Schwartzkroin PA, Messing A, Tempel BL (1998) Deletion of the $\mathrm{K}(\mathrm{V}) 1.1$ potassium channel causes epilepsy in mice. Neuron 20:809-819.

Somogyi P, Hodgson AJ, Smith AD, Nunzi MG, Gorio A, Wu JY (1984) Different populations of GABAergic neurons in the visual cortex and hippocampus of cat contain somatostatin- or cholecystokininimmunoreactive material. J Neurosci 4:2590-2603.

Steriade M (1997) Synchronized activities of coupled oscillators in the cerebral cortex and thalamus at different levels of vigilance. Cereb Cortex [Erratum (1997) 7:779] 7:583-604.

Steriade M, Contreras D (1998) Spike-wave complexes and fast components of cortically generated seizures. I. Role of neocortex and thalamus. J Neurophysiol 80:1439-1455.

Steriade M, Nunez A, Amzica F (1993a) A novel slow ( $<1 \mathrm{~Hz}$ ) oscillation of neocortical neurons in vivo: depolarizing and hyperpolarizing components. J Neurosci 13:3252-3265.

Steriade M, Nunez A, Amzica F (1993b) Intracellular analysis of relations between the slow $(<1 \mathrm{~Hz})$ neocortical oscillation and other sleep rhythms of the electroencephalogram. J Neurosci 13:3266-3283.

Steriade M, Amzica F, Contreras D (1996) Synchronization of fast (30-40 $\mathrm{Hz}$ ) spontaneous cortical rhythms during brain activation. J Neurosci 16:392-417.

Steriade M, Timofeev I, Durmuller N, Grenier F (1998) Dynamic properties of corticothalamic neurons and local cortical interneurons generating fast rhythmic $(30-40 \mathrm{~Hz})$ spike bursts. J Neurophysiol 79:483-490.

Stuart GJ, Dodt HU, Sakmann B (1993) Patch-clamp recordings from the soma and dendrites of neurons in brain slices using infrared video microscopy. Pflügers Arch 423:511-518.

Thomas KR, Capecchi MR (1987) Site-directed mutagenesis by gene targeting in mouse embryo-derived stem cells. Cell 51:503-512.

Traub RD, Whittington MA, Stanford IM, Jefferys JG (1996) A mechanism for generation of long-range synchronous fast oscillations in the cortex. Nature 383:621-624.

Traub RD, Jefferys J, Whittington M (1999) Fast oscillations in cortical circuits. Cambridge, MA: MIT.

Vega-Saenz de Miera E, Weiser M, Kentros C, Lau D, Moreno H, Serodio P, Rudy B (1994) Shaw-related $\mathrm{K}^{+}$channels in mammals. In: Handbook of membrane channels (Peracchia C, ed), pp 41-78. Orlando: Academic.

Velluti JC, Caputi A, Macadar O (1987) Limbic epilepsy induced in the rat by dendrotoxin, a polypeptide isolated from the green mamba (Dendroaspis angusticeps) venom. Toxicon 25:649-657.

Wang LY, Gan L, Forsythe ID, Kaczmarek LK (1998) Contribution of the Kv3.1 potassium channel to high-frequency firing in mouse auditory neurones. J Physiol (Lond) 509:183-194.

Weiser M, Vega-Saenz de Miera E, Kentros C, Moreno H, Franzen L, Hillman D, Baker H, Rudy B (1994) Differential expression of Shawrelated $\mathrm{K}^{+}$channels in the rat central nervous system. J Neurosci 14:949-972.

Weiser M, Bueno E, Sekirnjak C, Martone ME, Baker H, Hillman D, Chen S, Thornhill W, Ellisman M, Rudy B (1995) The potassium channel subunit KV3.1b is localized to somatic and axonal membranes of specific populations of CNS neurons. J Neurosci 15:4298-4314.

Xu J, Yu W, Jan YN, Jan LY, Li M (1995) Assembly of voltage-gated potassium channels. Conserved hydrophilic motifs determine subfamilyspecific interactions between the alpha-subunits. J Biol Chem 270:24761-24768.

Zhu JJ, Connors BW (1999) Intrinsic firing patterns and whisker-evoked synaptic responses of neurons in the rat barrel cortex. J Neurophysiol 81:1171-1183. 